Article

\title{
Effects of Climatic Warming and Wildfires on Recent Vegetation Changes in the Lake Baikal Basin
}

\author{
Alexander N. Safronov (D) \\ A.M. Obukhov Institute of Atmospheric Physics, Russian Academy of Sciences, Pyzhevskii per. 3, \\ 119017 Moscow, Russia; safronov_2003@mail.ru; Tel.: +7-495-953-3762
}

Received: 16 March 2020; Accepted: 14 April 2020; Published: 16 April 2020

\begin{abstract}
The vegetation changes in the area of the Russian part of the Lake Baikal water basin for the period 2010-2018 were investigated using MCD12C1 land cover. The decline in swamp systems area began in 2012 and continued until 2015, after which it partially recovered during the heavy rain season in 2018. During the period of 2010-2018, the area covered by forests did not exceed $20.3 \%$ of the Baikal basin of the total portion of the Baikal basin under study. Deforestation began in 2013 and continued until 2017. Over 2013-2018, the forest level decreased by 12.1\% compared to the forest state in 2013 . The analysis of summer rainfalls and aridity indexes was performed by using CRU TS and GPCC climatic datasets. It is shown that the interannual variations of precipitation and aridity changes are determined by the variability of the global circulation of moist air masses. The MCD64A1 (burned area) and MCD14ML (active fires) MODIS products were used for investigation of the influence of wildfires on vegetation changes. The spatial hotspot distributions and burned areas in general correspond to aridity zones, but they cannot explain the 20-fold increase in the number of wildfires. Most of the hotspot locations are away from settlements, roads, and loggings, in difficult-to-access mountainous areas, as well as in the low-inhabited areas of Siberia. We assume that the nature of such ignitions includes dry thunderstorms, pyrocumulus lightning, or remote impact.
\end{abstract}

Keywords: Baikal basin; land-cover change; climate change; wildfires; MODIS

\section{Introduction}

To understand and respond to global environmental changes, such as global warming and biodiversity loss, a timely assessment of deforestation and land-cover degradation is required. Since satellites can periodically provide images covering wide areas, global monitoring using satellite remote sensing is one of the most effective approaches to detect changes on the Earth's surface. In this study, we investigated the changes in land cover nearby Lake Baikal. Lake Baikal is the deepest and largest freshwater reservoir on Earth, holding $20 \%$ of the world's total unfrozen fresh water.

The lake is fed by an inflow of water from areas lying east and south of the Baikal (Figure 1). Moreover, the largest river, Selenga, running into Lake Baikal, provides up to half of the annual inflow of water. The water regime of the river Selenga is characterized by low spring flood, rainfall floods in summer, and moderate inflow by autumn-winter. The changes in water inflow into Lake Baikal and runoff fluctuations in the Selenga river basin were studied in References [1-9].

In this work, the natural climatic changes in the Baikal basin, as well as methods of natural landscape restoration, were investigated. Since these methods are supervised by administrative resources, our investigation is restricted only to the area corresponding to the Russian part of the Lake Baikal water basin. Note that our study of the Lake Baikal biosphere is a part of a more general project devoted to the investigation of changes in the water table level; thus, the time range in our study is limited to the interval 2010-2018. 


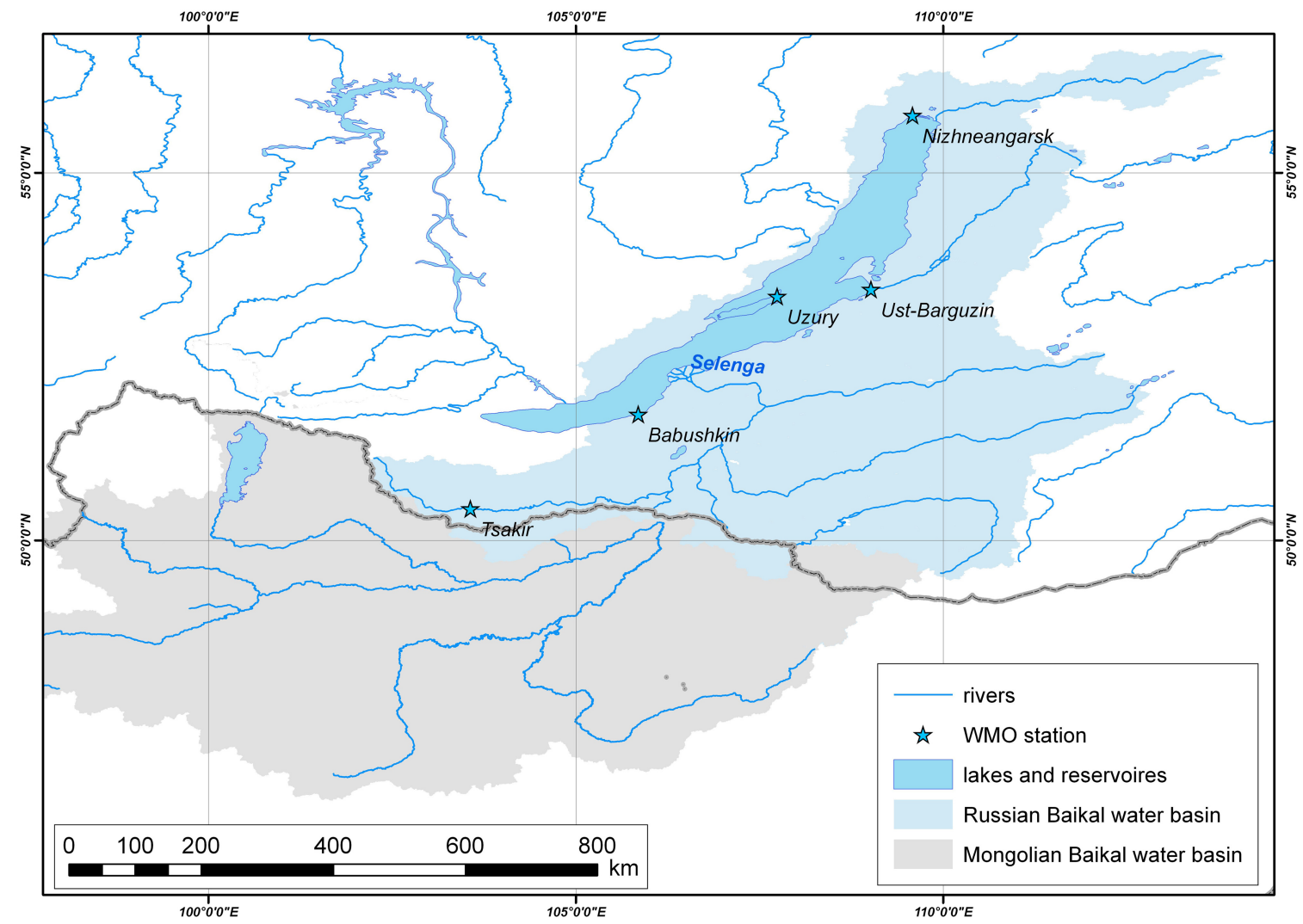

Figure 1. Overview of the Lake Baikal basin region; Russian and Mongolian parts are marked as blue and gray areas, respectively. The country boundary is shown as a bold gray line.

The Selenga river valley belongs to the steppe and forest-steppe zones [10-12]. The mountain ranges along the river are covered with pine forests with undergrowth up to heights of $650-800 \mathrm{~m}$. In some places, the inter-mountain depressions are covered by steppes, which, in turn, are surrounded by forests. Inside them, the pine forest is interspersed with dry steppes, while, in the narrow pads, there are birch forests mixed with aspens and pines. In addition, along the banks of the Selenga River, bird cherry trees are growing.

Note that, in Reference [13], the results of vegetation and soil cover study in the forest-steppe landscapes of the Russian and Mongolian parts of the Lake Baikal basin, were presented. It was shown that deforestation is one of the most important environmental problems of the Lake Baikal basin, and it was noted that, at present, the probability of a favorable combination of factors of natural regeneration of forests in the southern part of the Baikal basin is low.

Climate-induced mortality of Siberian pine and fir in the Lake Baikal basin was reported in References [14,15], while, in Reference [16], climate-induced birch mortality in the trans-Baikal lake region was mentioned. The details of water and environment in the Selenga-Baikal basin can be found in Reference [17].

Changes in the summertime atmospheric circulation over East Asia and formation of long-lasting low-water periods of 1976-1982 and 1996-2011 within the Selenga-Baikal river basin were investigated in Reference [18], where it was concluded that the circulation in the zone of convergence of monsoon flows and mid-latitude flows over Mongolia and North China is probably one of the reasons for the low-water periods. As it is known, the interannual variations in the water-saturated air mass intake are determined by the variability of global air circulation. However, in addition to rainfall, a process of evaporation of moisture from the surface also affects the general water balance. This process is determined by the composition of soils and growing vegetation in the study area. The rapid restoration of vegetation, which suffers climatic changes, wood wreckers, or wildfires, is an important task. 
The long-term trends and correlations between normalized difference vegetation index (NDVI) and climate variables over 1982-2014 in Asia, based on AVHRR-GIMMS satellite data, were studied by Lamchin et al. [19]. Furthermore, the trends of climate (1979-2016) and land-cover changes (2000-2010) obtained by the Landsat Thematic Mapper (TM) and the Landsat Enhanced Thematic Mapper (ETM+) with a resolution of $30 \mathrm{~m}$ in the Lake Baikal basin, can be found in Reference [8]. Similarly, the response of grassland and forest to temperature and precipitation in the Selenga-Baikal basin from 1982-2015 can be found in a recently published study by Wang and colleges [20].

Information about the variations in temperature may be found in several studies. In particular, the spatial distributions of the change in trends of seasonal temperature and precipitation over the Selenga-Baikal Basin were presented in a recently published paper [20]. According to Wang et al. [20], the change in the summer temperature is in the range of $0.010-0.025^{\circ} \mathrm{C} /$ year. Such values of temperature change are small with a significant direct effect on vegetation growth. The investigations of variability of monthly precipitation, evaporation, and aridity index are more important to understand the response in the ecosystems.

The purpose of our research is to study the reason for forest losses. Note that the forest losses are caused mainly by the following factors:

$$
\text { forest losses }=\text { commercial deforestation }+ \text { climate changes }+ \text { wildfires } .
$$

In our study, the contribution of commercial deforestation was small due to the forest being located in a national biospheric reservation. In the reservation, deforestation is defined by the sanitary logging of forests, as well as trees damaged by wildfires, by bark beetle bugs, and droughts. Thus, in our case, the forest loss is characterized both by climate change and by wildfires.

$$
\text { forest loss }=\text { climate changes }+ \text { wildfires. }
$$

Furthermore, it is well known that wildfire ignitions happen basically in $99 \%$ of cases because of anthropogenic reasons, such as dry grass burning on arable lands, campfires made by tourists and hunters in improper places, garbage ignition, smoking, burning of dry branches at loggings, and other industrial activity (see Equation (2)). In this study, in addition to taking the surface anthropogenic factor into consideration, we entered a new remote anthropogenic factor.

$$
\begin{aligned}
& \text { wild fires ignitions }=\text { anthropogenic factor }+ \text { natural reasons of ignitions, } \\
& \text { where } \\
& \text { anthropogenic factor }=\text { surface }+ \text { remote impacts, } \\
& \text { natural reasons }=d r y \text { thunderstorms }+ \text { aerosol (pyrogenic) thunderstorms. }
\end{aligned}
$$

Therefore, our work consists of two parts. The first part is devoted to studying the climate change influence on forest loss. This part is routine and will scarcely raise the interest of climatologist and forest scientists. The presence of planetary frequencies in climatic trends is confirmed, while it is a surprise only for astronomers and populists. The second part of our study is devoted to wildfires (Equation (1b) and Equation (2)). It is useful to note the difference between two types of thunderstorms, which can lead to forest fire ignitions. Dry thunderstorms have a negative downward leader from clouds to ground (normal strike), whereas aerosol (pyrogenic) thunderstorms usually have a negative upward leader from ground to clouds (reverse strike). Below, it is shown that the spatial distribution of wildfires in the national biospheric reservation does not correlate with surface anthropogenic activities. Therefore, this part of the study raises hot debates and will probably be interesting for a wide range of readers. 


\section{Materials and Methods}

\subsection{The MCD12C1 Land-Cover Map}

In this study, the vegetation changes were analyzed using satellite maps of MCD12C1, Collection C6 land cover in the 2010-2018 period. The MCD12C1 land-cover maps were created using MODIS spectrometers installed on the Terra and Aqua satellites (NASA) [21,22]. The MCD12C1 land-cover maps have $0.05^{\circ}$ spatial resolution in latitude/longitude projection, and they can be considered as a re-projected version of the tiled MCD12Q1 product. A detailed description of MCD12C1 and MCD12Q1 can be found in Reference [23].

In our research of the Baikal, the IGBP vegetation type classification (the International GeosphereBiosphere Program), including 16 species of vegetation, was used; for convenience, the IGBP types are presented in Table S1 (Supplementary Materials). As already specified earlier in References [24,25], the global land-cover satellite maps are not well adapted to the local natural-climatic zones, and using MCD12Q1/MCD12C1 land-cover maps makes no exception.

Therefore, it is not surprising that acacia bushes in Africa savannas have a spectral composition similar to thinned (open) larch forests in western Transbaikalia. According to IGBP type, savannas are a territory in which trees, with a height of more than $2 \mathrm{~m}$, cover $10 \%-30 \%$ of the pixel area.

For type correction, the 2004 Russian Forest map designed by Bartalev et al. could be used [26]. The pine, larch, broadleaved deciduous, stone birch, dwarf pine birch-aspen, and mixed forest categories were identified in this map; however, it does not allow analyzing the vegetation changes, which is the object of our study. Note that the problems of adaptation of spectral satellite images with specific Russian vegetation types were discussed in References [27-32]. As an example, the comparison between the spatial distribution of vegetation of MCD12C1 (2018) land cover and the spatial forest distribution of the Russian Forest (2004) map is presented in Figure 2. Taking into account the above remarks, we carried out our investigation of MCD12C1 land-cover changes. 

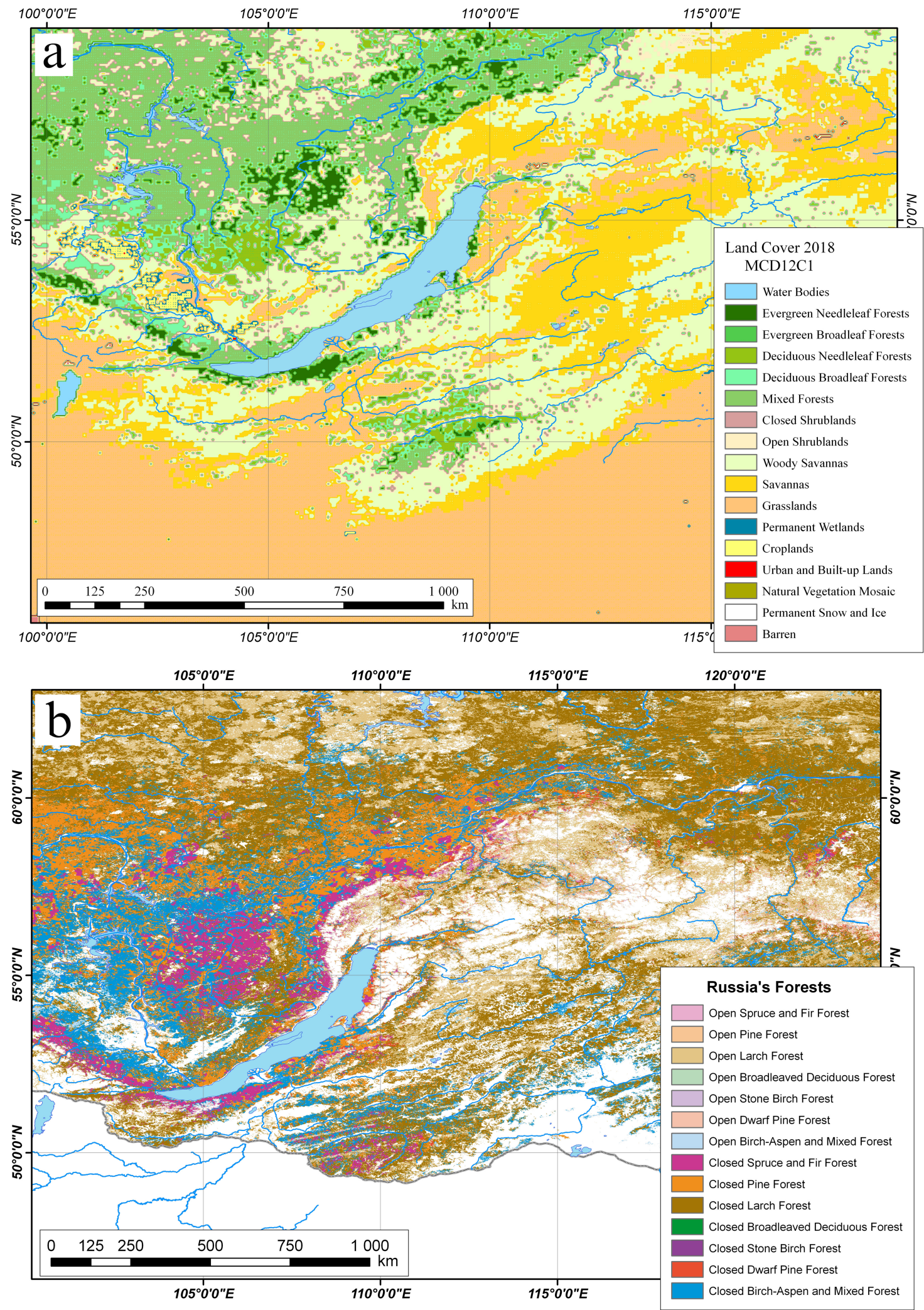

Figure 2. (a) MCD12C1 land-cover map nearby Lake Baikal in 2018. The spatial resolution of the map is $0.05^{\circ}$. The vegetation legends correspond to the International Geosphere-Biosphere Program (IGBP) classes. (b) The Russian Forest map in 2004. 
In this work, for land-cover description, we used the relative land cover (RLC), defined as follows:

$$
\begin{aligned}
& R L C_{i}=\frac{1}{N} \sum_{S} \text { pixels }_{i} \times 100 \%, \\
& N=\sum_{i}^{I G B P} \sum_{S} \text { pixels }_{i},
\end{aligned}
$$

where $i$ is the type of vegetation $(0,1, \ldots, 15$ for IGBP), $S$ is the study area, and $N$ is the total number of all pixels in the study area. The RLC $\mathrm{i}$ is measured as a percentage and indicates how the $i$-type of vegetation propagates in the study territories.

The temporal land-cover changes are characterized by relative land cover changes $\left(\triangle R L C_{i}\right)$, as a percentage of total area, or by changes normalized on average account of $i$-type pixels.

$$
\begin{aligned}
& \Delta R L C_{i}=R L C_{i}\left(T_{1}\right)-R L C_{i}\left(T_{2}\right), \\
& \Delta L C_{i}=\frac{\Delta R L C_{i}}{\left\langle R L C_{i}\right\rangle_{T}} \times 100 \%,
\end{aligned}
$$

where $T_{1}, T_{2}$ are selected temporal intervals (in our case $T_{1}=2010$ and $T_{2}=2018$ ), and $\left\langle R L C_{i}\right\rangle_{T}$ is the average relative land cover, which is equal to the half-sum of $R_{L} C_{i}$.

\subsection{The CRU TS Climatic Dataset and Aridity Index}

Furthermore, in our study, we compare both the dynamics of precipitation and the aridity index to vegetation change. The high-resolution climate gridded dataset CRU TS Version 4.03 (Climatic Research Unit) was used (Dataset CRU TS4.03). It covered the 1901-2018 global land data for monthly precipitations on a $0.5^{\circ} \times 0.5^{\circ}$ latitude/longitude grid. This dataset was generated by the University of East Angelia, United Kingdom (UK), through interpolation of the records from more than 4000 precipitation reporting meteorological stations. It covers all land areas of the Earth and incorporates cloud cover (CLD), diurnal temperature range (DTR), mean daily temperature (TMP), air maximum and minimum temperatures (TMN and TMX), monthly average precipitation total (PRE), vapor pressure (VAP), wet day frequency (WET), relative humidity (RHM), ground frost day frequency (FRS), and potential evapotranspiration (PET). More details can be found in Reference [33]. This gauge-based global dataset, released on 15 May 2019, is available for download from the site of the University of East Anglia, Norwich, UK [34].

Note that, in the Selenga-Baikal basin, the relationships between the dynamics of the normalized difference vegetation index (AVHRR, NDVI) and monthly gridded temperature and precipitation data from CRU version TS4.00 were investigated in Reference [20] for the period between 1982 and 2015.

The aridity index (Ia) over the 2010-2018 period for the summer season (June-August) was calculated using CRU TS Version 4.03 precipitation and potential evaporation data; the aforementioned index is defined as

$$
I_{a}=\mathrm{prec} / \mathrm{pet},
$$

where prec is the precipitation, ( $\mathrm{mm} / \mathrm{month})$, pet is the potential evaporation, $(\mathrm{mm} / \mathrm{month})$, and the aridity index is unit-less.

On the basis of the Ia index, the climatic zones in China are usually classified as arid (Ia $\leq 0.2)$, semiarid (0.2< Ia $\leq 0.5$ ), and humid (Ia > 0.5) (see, for example, Reference [35]). Thus, Ia $=0.2$ is the arid-semiarid boundary and Ia $=0.5$ is the semiarid-humid boundary.

However, in the areas of land aridization in Transbaikalia, the arid climate zones are usually classified as follows: semiarid $(0.2<$ Ia $<0.5)$, dry subhumid $(0.5<$ Ia $<0.65)$, semiarid subhumid $(0.65<$ Ia $<0.75)$, and moist subhumid and humid (Ia $>0.75)$ [36]. Information about the aridity index in the Lake Baikal basin can also be found in References [4,5]. 


\subsection{The GPCC Precipitation Analysis Products}

Due to the fact that precipitation data may vary, in this study, in addition to the CRU TS dataset, the Global Precipitation Analysis Products of the Global Precipitation Climatology Center (GPCC, Version 2018) were used [37]. This GPCC dataset is also a gauge-based analysis dataset with a spatial $0.5^{\circ} \times 0.5^{\circ}$ latitude/longitude resolution; however, unlike the CRU TS, it provides monthly precipitation values only until December 2016. The GPCC description is available in References [38,39]. The GPCC data can be downloaded from Deutscher Wetterdienst (DWD, National Meteorological Service of Germany). The comparison of different techniques and rainfall data can be found in a previous review [40].

\subsection{The Forest and Grassland Hotspot Location Analysis}

The fire situation in the area of the Lake Baikal basin was analyzed by data derived from MODIS spectrometers which were installed on the Terra and Aqua NASA satellites. Firstly, we used the active fires (AF) product of MODIS spectrometers. The MCD14ML product, created in the University of Maryland, combines the infrared data from both satellites and presents data as monthly hotspot locations on a geographic map. A detailed description can be found in References [41-43]. The MCD14ML product can be downloaded from the University of Maryland FTP Server (fuoco.geog.umd.edu). A number of factors, such as smoke from wildfires, glare from the sun, and the Earth's surface scanning at high angles from the nadir, can affect the quality of signal reception. In this study, only hotspots that were registered with high confidence (more than $75 \%$ ) were taken into account.

\subsection{The Burned Areas}

Fire situations nearby Lake Baikal were analyzed by using the burned areas (BA) MODIS product. The description of the MCD64A1 C6 collections of the BA product can be found in References [44-46]. Note that the burned areas were determined by using both the MODIS active fire product data and the changes in the burn-sensitive MODIS vegetation index (vegetation index, VI). The VI index was defined as follows:

$$
V I=\frac{\rho_{5}-\rho_{7}}{\rho_{5}+\rho_{7}}
$$

where $\rho_{5}$ and $\rho_{7}$ are the corrected surface reflectivity of the short-wave infrared 5 and 7 channels of MODIS spectrometers. Convenient GeoTIFF and Shapefile formats of the MCD64A1 product for use in geographic information system (GIS) map systems (ESRI ArcInfo) are available for download from the FTP server of the University of Maryland: ftp:ba1.geog.umd.edu.

\subsection{GIS System Tool and Water Bodies Recourse}

In this study, ESRI ArcInfo was used as the GIS system tool (geographic information system) for calculating, analyzing, and clipping data, cartography, and visualization. In particular the aridity indexes were calculated using this tool. The detailed information about the ArcInfo GIS system can be found on the ESRI Corporation website [47]. Furthermore, during this study, we used the global water basin dataset, called World Water Bodies. This resource is provided by the DeLorme Publishing Company and can be freely download from the UCLA geoportal [48]. The World Water Bodies resource has an SHP (shape) format; such a geospatial vector data format is convenient for use in ESRI ArcInfo.

\section{MCD12C1 Land-Cover Changes}

\subsection{The Temporal Variability of MCD12C1 Vegetations Nearby Lake Baikal}

The dynamics of areas covered by the total forest (all categories) and swamp systems are presented in Figure 3 as a percentage of area of the Russian part of basin. Note that, in 2010-2018, decreases were observed in both categories. An analysis of the areas occupied by swamp systems shows that the permanent wetland area occupies only $0.10 \%-0.16 \%$ of the observed region. The decline in swamp system area began in 2012 and decreased until 2015, before partially recovering in 2018. The area 
covered by total forests does not exceed $20.3 \%$ of the total studying area. The deforestation began in 2013 and continued until 2017. In the period between 2013 and 2018, the forest area decreased by $2.45 \%$ of the total area under study, or by $12.1 \%$ of the forest state in 2013.

The forests are basically growing in the lowlands between hills, along the rivers. Thus, it is important to study the change in water surface, especially because this work is part of a hydrological project. The water surface area started rapidly decreasing in 2015 and continued decreasing until the end of the considered time interval. Over the period of 2010-2018, the water surface area decreased by $0.12 \%$. In previous studies, particularly in Reference [20], this question was not investigated. Note that, the behaviors of the changes in the permanent wetland and water surface areas were completely different (Figure 3b). Several factors can affect the water surface value, including water balance between inflows and outflows of Baikal streams, precipitation and evaporation, water tables of swamps and rivers in the Baikal basin, and others.
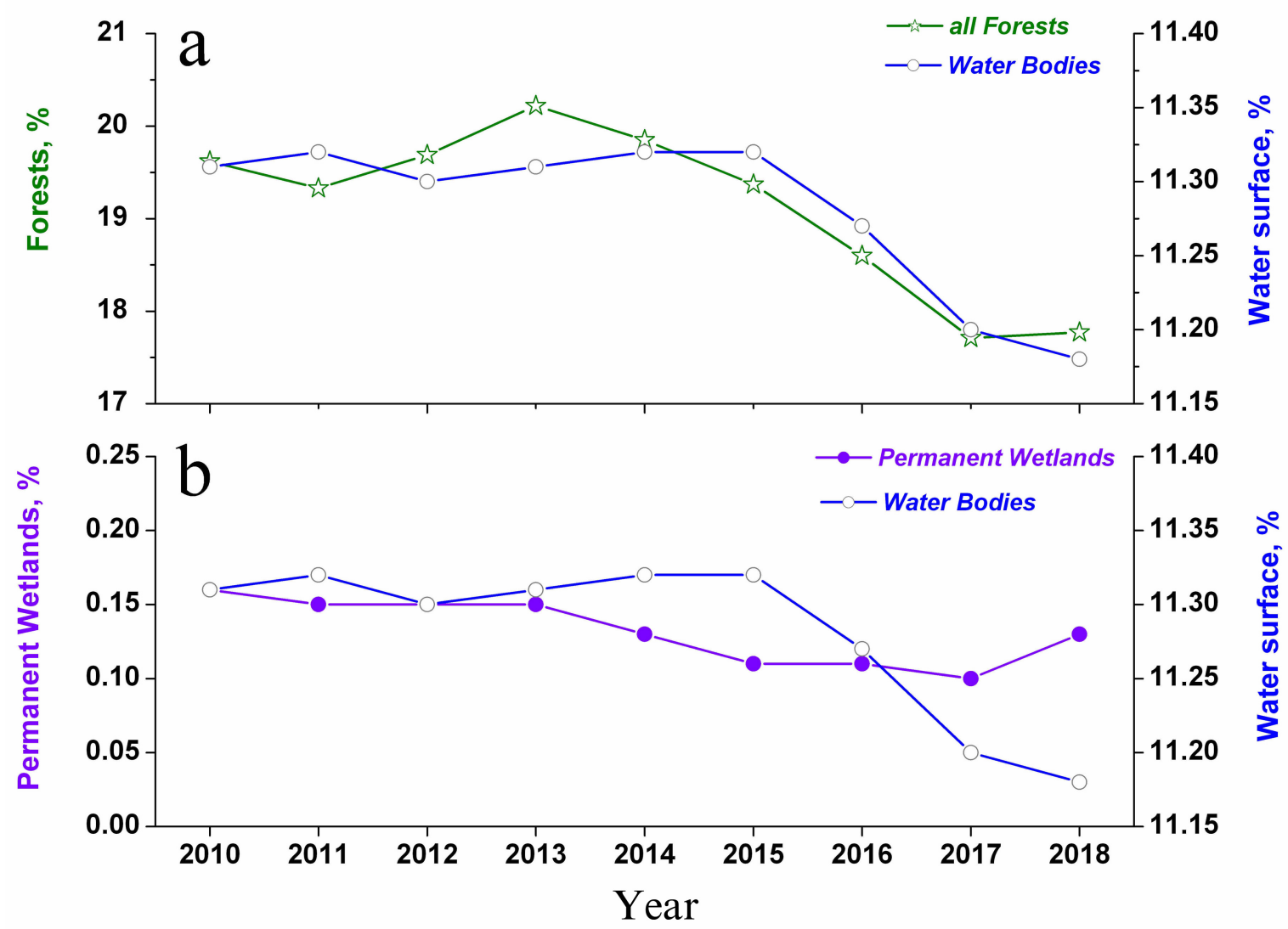

Figure 3. The interannual variability of areas occupied by forests (a) and by swamp systems (b), as a percentage of the Russian basin of the Lake Baikal as a function of time for the period 2010-2018, considered in this paper. The area of water surface is presented for comparison. The vegetation types in MCD12C1 correspond to IGBP classes.

The forest type changes are presented in Figure 4. The decrease in area occupied by evergreen, deciduous, and mixed forests began in 2013. After a rainy 2018, some stabilization in the distribution of deciduous needleleaf and deciduous forests was observed. 


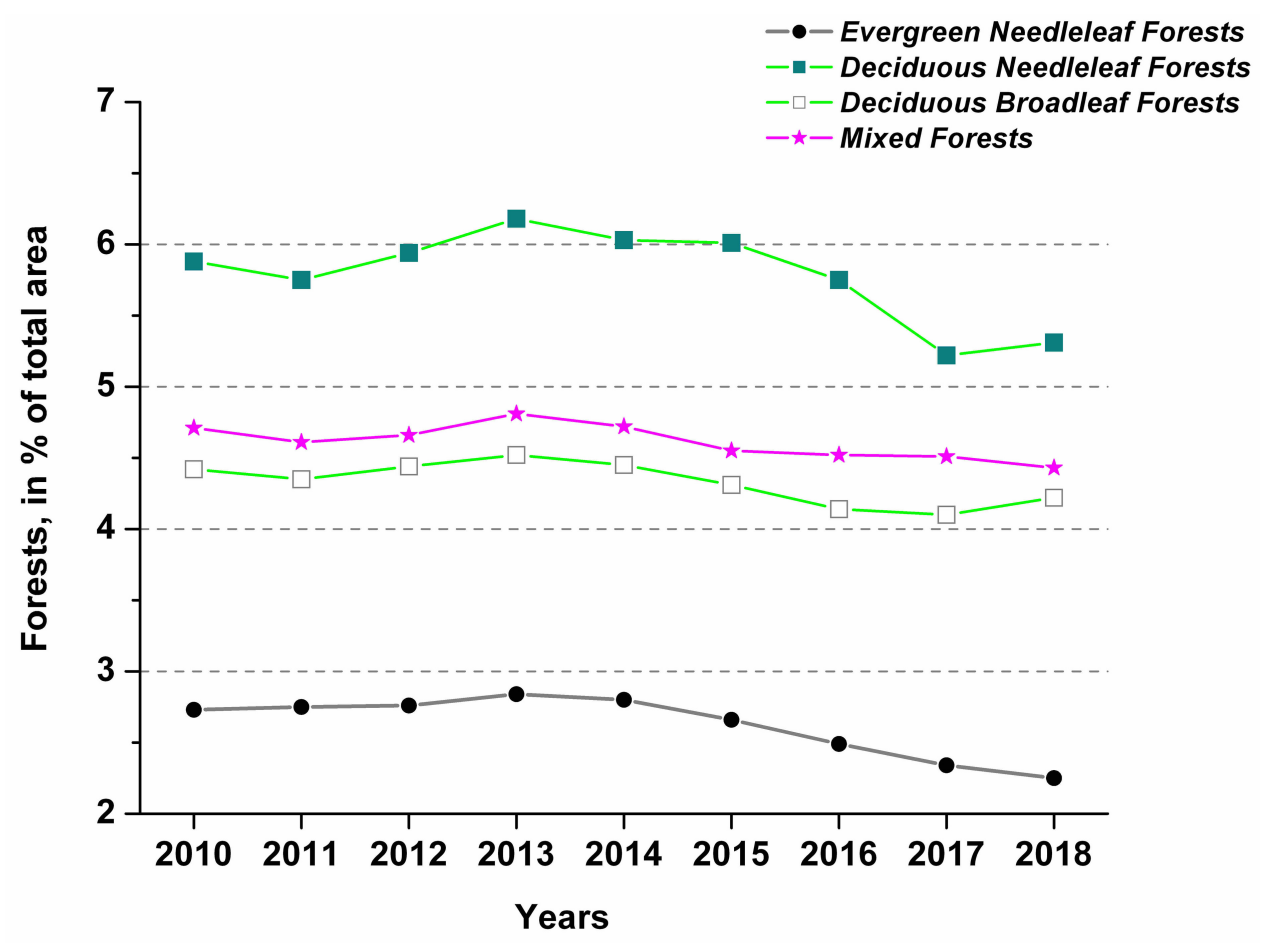

Figure 4. The interannual variability of areas occupied by evergreen needleleaf, deciduous needleleaf, deciduous broadleaf, and mixed forests as a percentage of the Russian basin of Lake Baikal, is presented as a function of time for the period 2010-2018, considered in this paper. The vegetation types in MCD12C1 correspond to IGBP classes.

The variations in the areas occupied by shrubs, steppes, and grasslands are presented in Figure 5. The decreases over the five-year period between 2013 and 2018 are recorded in the areas covered by open and closed shrublands (Figure 5a). However, in the same period of time, an increase in areas covered by steppes (savannas) and forest-steppes (woody savannas) was observed (see Figure 5b); overall, the territory occupied by steppes and forest-steppes increased by $3.8 \%$.

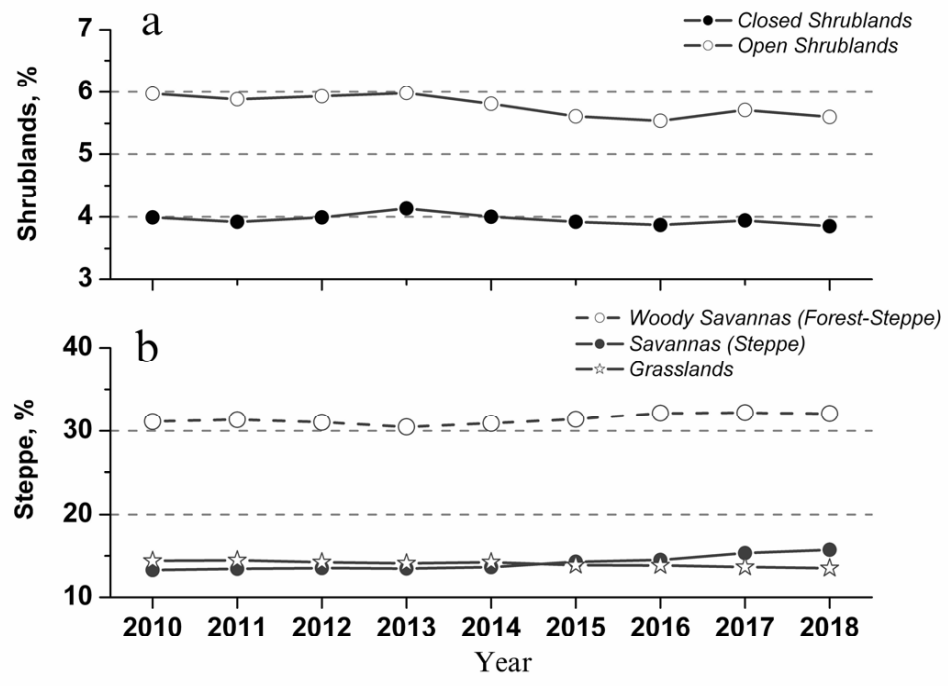

Figure 5. The inter-annual variability (as a percentage of the Russian sector of Lake Baikal basin) of areas occupied by open and closed shrublands (a) and forest-steppe/steppe/grassland (b), as a function of time. The vegetation types in MCD12C1 correspond to IGBP classes. 
The results of MCD12C1 land cover are summarized in Table 1. All these changes in vegetation correspond to climate warming, changes in the climatic conditions of their growth, and area forest and shrubland changes in steppes and forest-steppes.

Table 1. The MCD12C1 land cover, as a percentage of the total studied area, inside the territory of Lake Baikal basin, in 2010 and 2018. The IGBP category system of land cover was used. The gray-shaded box around woody savannas and savannas highlights the essentially increasing values of these categories.

\begin{tabular}{|c|c|c|c|c|}
\hline \multirow{2}{*}{ IGBP Category } & \multicolumn{2}{|c|}{ Relative Land Cover (RLC), \% } & \multicolumn{2}{|c|}{ Changes, 2018-2010 } \\
\hline & 2010 & 2018 & $\Delta R L C, \%$ & $\Delta L C, \%$ \\
\hline Water bodies & 11.31 & 11.18 & -0.12 & -1.1 \\
\hline Evergreen needleleaf forests & 2.73 & 2.25 & -0.47 & -18.9 \\
\hline Evergreen broadleaf forests * & 1.88 & 1.56 & -0.33 & -19.2 \\
\hline Deciduous needleleaf forests & 5.88 & 5.31 & -0.57 & -10.2 \\
\hline Deciduous broadleaf forests & 4.42 & 4.22 & -0.20 & -4.6 \\
\hline Mixed forests & 4.71 & 4.43 & -0.29 & -6.3 \\
\hline Closed shrublands & 3.99 & 3.85 & -0.14 & -3.6 \\
\hline Open shrublands & 5.97 & 5.60 & -0.37 & -6.4 \\
\hline Woody savannas (forest-steppe) & 31.13 & 32.10 & 0.97 & 3.1 \\
\hline Savannas (steppe) & 13.33 & 15.72 & 2.39 & 16.5 \\
\hline Grasslands & 14.42 & 13.55 & -0.87 & -6.2 \\
\hline Permanent wetlands & 0.16 & 0.13 & -0.02 & -13.8 \\
\hline
\end{tabular}

* This type of forest is absent in the vicinity of lake Baikal. The MODIS spectral signal probably corresponds to a two-layer forest, the upper layer of which is formed by old deciduous broadleaved cover and the lower layer of which is formed by young spruce.

\subsection{The Variability of Spatial Distribution of MCD12C1 Forests Nearby Lake Baikal}

In this section, we present forest changes by comparing the MCD12C1 spatial distributions between 2010 and 2018. The stress-non-stress forest maps are presented in Figure 6. Green pixels are pixels in which the forest in 2010 saved its own IGBP type (non-stress). Red pixels give the stress mask, i.e., pixels, in which forests growing in 2010 substantially changed their structure or completely disappeared. The spatial distribution of forests in 2010 was chosen as the background map; thus, the stress layer (red pixels) overlaps the background forest in 2010. As can be seen from this Figure, the main changes in forests are located in the north/northwest of Lake Baikal. Changes in the structure of forests are significant, but they all appear to be mainly outside of the Lake Baikal basin area, i.e., outside of our study area. 


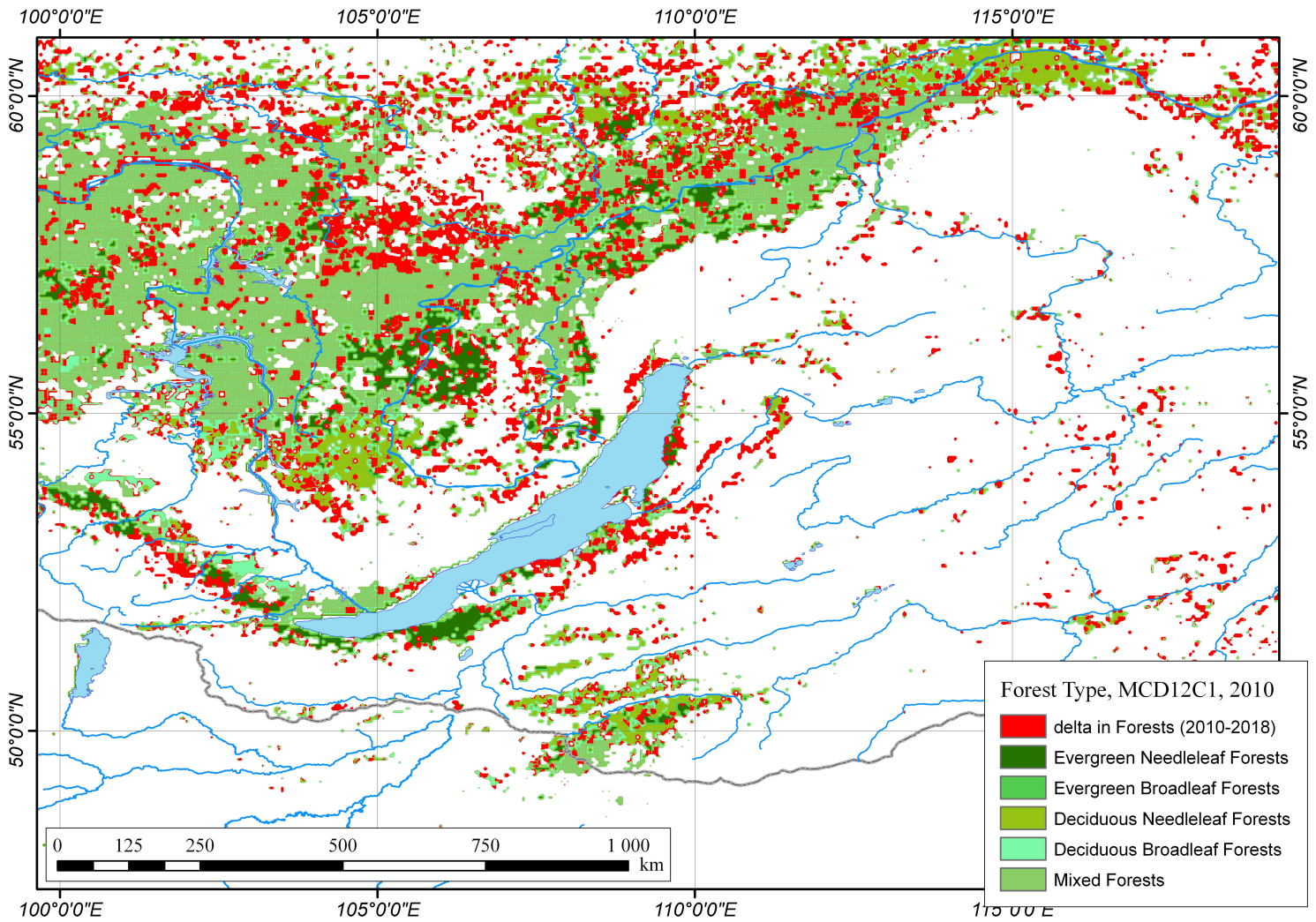

Figure 6. Changes in forest structure nearby Lake Baikal aimed at comparing the MCD12C1 forest distribution in 2010 and 2018. The forest cover was determined from the original MCD12Q1 maps, with $100 \%$ pixel coverage. The spatial resolution of the MCD12C1 map is $1 \mathrm{~km}$. The red-colored pixels indicate areas where forests, grown in 2010, completely disappeared or their structure was significantly changed in 2010-2018. In addition, the spatial distribution of forests in 2010 is shown as green-colored sectors.

\section{The Analysis of Climatic Changes in the Baikal basin}

As it is well known, many factors can affect vegetation changes, including warming, drought, and wildfires. In Section 4, we pay attention to changes in the environment. The influence of wildfires on vegetation change are considered in Section 5.

The moisture content of air masses in the area of the Lake Baikal water basin is determined by the general circulation of air masses, which can vary from year to year. Therefore, drought periods on Lake Baikal are replaced by periods with heavy rainfall, which are formed over both the Western Siberia marshes and the Pacific monsoons, which could reached the boundary of the Baikal water basin. The Lake Baikal basin is mainly filled by precipitation on the territories lying east and south of Lake Baikal (Figure 1). The largest river, the Selenga, flowing into Lake Baikal, provides up to half of the annual inflow of water [49]. Moreover, the water regime of the Selenga River is characterized by low spring water level, rain floods in summer, and low water in winter. The hydrological parameters of the Selenga river can be found in References [49-52].

\subsection{The Spatial Distribution of Summer Rainfalls}

The climatic precipitation datasets were used for investigation of the spatial distributions of rainfall in the Lake Baikal basin for the period from 2010 to 2018. As it is known, gauge-based climatic precipitation datasets can differ from each other; therefore, in our study, two independent databases were applied.

As an example, the distributions of rainfall obtained by CRU TS and GPCC datasets are compared in Figures 7 and 8, respectively. In each figure, we also compare the spatial precipitation distributions 
in the relatively wet summer of 2010 and the abnormally dry 2015. In the summer of 2010, the distributions are typical. A dry June (Figures $7 a$ and $8 a$ ) is replaced by a rainy season from July-August (see panels c and e in Figures 7 and 8). However, in the abnormally dry summer of 2015, the wet season was less expressed and the rainfall was significantly less (see panels b, $d$, and $f$ in Figures 7 and 8). Thus, we demonstrate that the spatial distribution of rainfall in the summer in the Lake Baikal basin can vary significantly. Note that these results were obtained from two independent gauge-based analysis datasets.
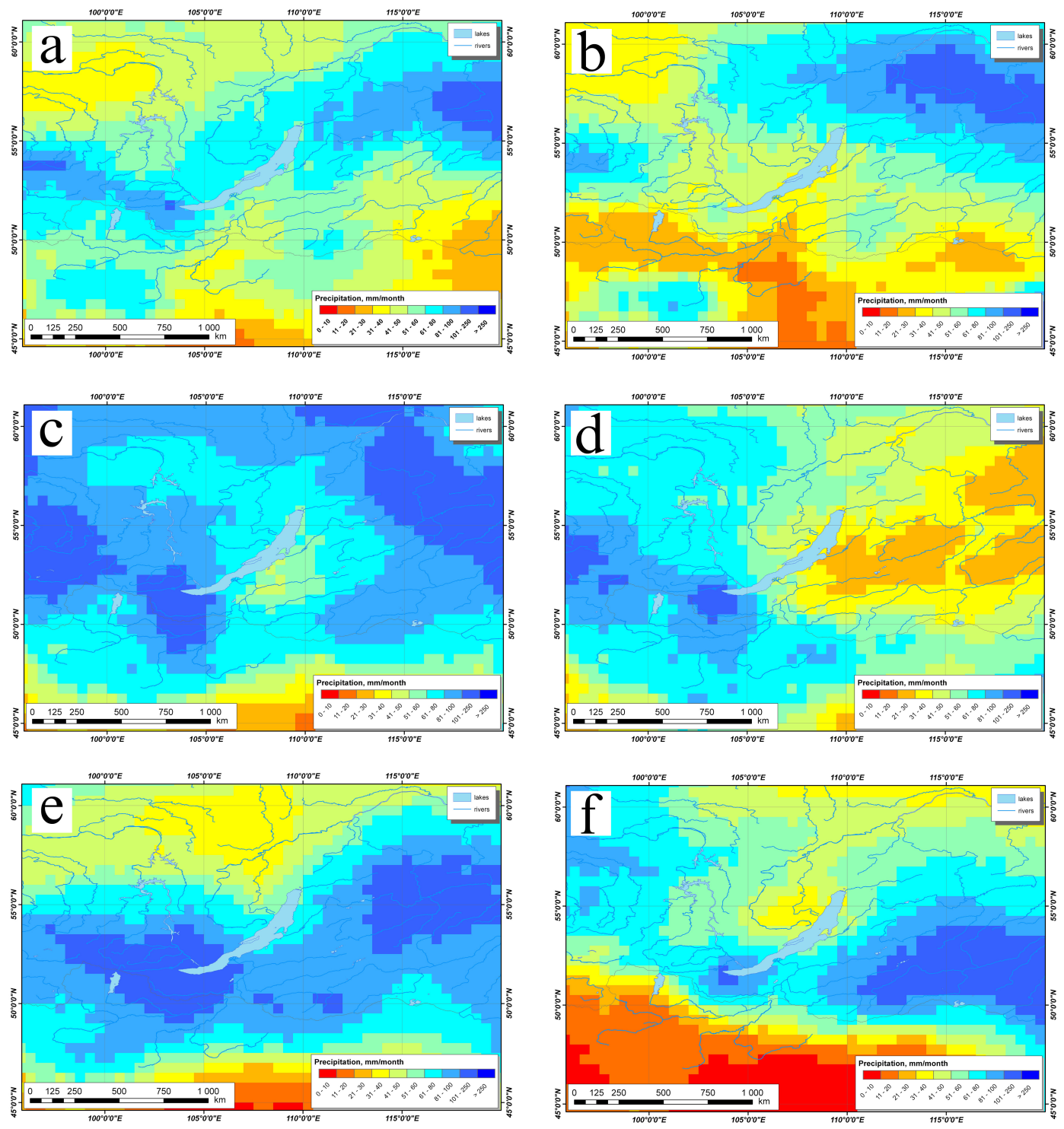

Figure 7. The comparison between the spatial distribution of CRU TS (Climatic Research Unit) monthly precipitation (mm/month) in the relative wet 2010 summer (a,c,e) and in the abnormally dry 2015 summer $(\mathbf{b}, \mathbf{d}, \mathbf{f})$ is shown. Panels $(\mathbf{a}, \mathbf{b})$ correspond to June, $(\mathbf{c}, \mathbf{d})$ correspond to July, and $(\mathbf{e}, \mathbf{f})$ correspond to August. 

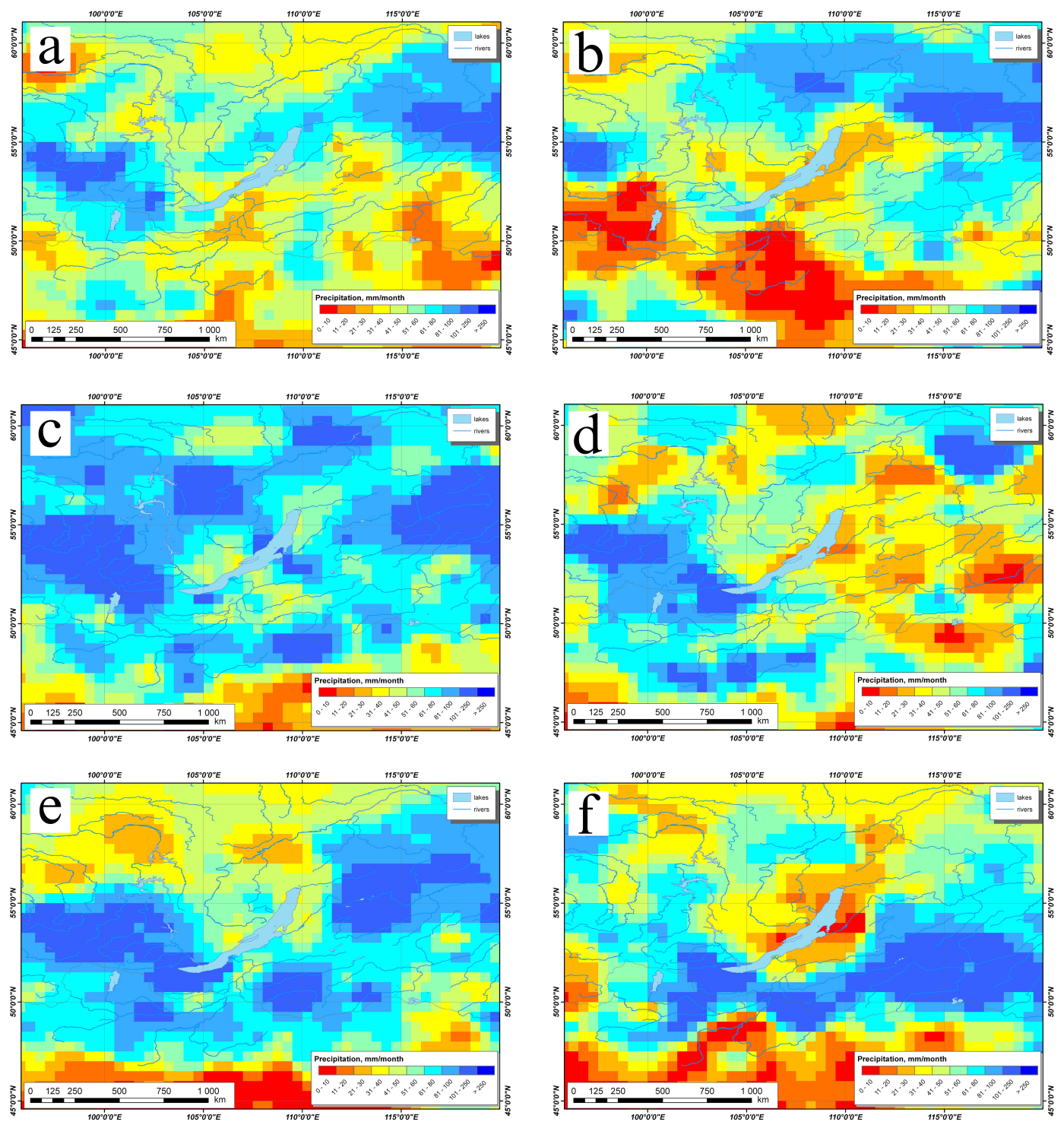

Figure 8. The comparison between the spatial distribution of Global Precipitation Climatology Center (GPCC), Version 2018 climatic precipitation dataset monthly precipitation ( $\mathrm{mm} / \mathrm{month}$ ) in the relative wet 2010 summer $(\mathbf{a}, \mathbf{c}, \mathbf{e})$ and in the abnormally dry 2015 summer $(\mathbf{b}, \mathbf{d}, \mathbf{f})$ is shown. Panels $(\mathbf{a}, \mathbf{b})$ correspond to June, $(\mathbf{c}, \mathbf{d})$ correspond to July, and $(\mathbf{e}, \mathbf{f})$ correspond to August.

\subsection{Annual Variability of Rainfall in the Lake Baikal basin}

In addition to the spatial precipitation distributions, it is of interest to define the annual variability of monthly summer rainfall, as well as to compare the amount of precipitation, occurring in the Russian and Mongolian part of the Baikal basin. As done in the previous section, the calculations were performed using the CRU TS and GPCC datasets.

The results of calculations are presented in the form of monthly rainfall in the rainy season (July-August), dry period (June), and across summer (i.e., June-August), averaged over the areas of the Russian and Mongolian parts of the water basin (see Figure 9).

Figure 9 presents the average precipitation, calculated as follows:

$$
<\text { prec }>=\left\langle\frac{1}{N_{0}} \sum_{i=1}^{\text {No }} \text { prec }_{i}\right\rangle_{T},
$$


where $N_{0}$ is the count of CRU/GPCC pixels in the Russian or Mongolian part of the Baikal basin, and $\operatorname{prec}_{i}$ is the CRU/GPCC precipitation of $i$-type pixel. For comparison, in the curves in Figure 9, the $i$-type pixel precipitation is normalized to one month, i.e., additional temporal averaging was done for summer (dashed gray line) and for the rainy season (blue line). The $<$ prec $>$ unit is $\mathrm{mm} / \mathrm{month}$.

In the Russian part of the basin, from 2012 to 2015, during the rainy period, a decrease in precipitation was observed (see Figure 9a,b, blue lines). The extreme situation in the Russian part occurred in 2014 and 2015. However, since 2016, in the rainy season, there was a positive trend. During the dry period, in the Russian part of the Baikal basin, the negative trend began in 2012 and extended until 2017 (until 2016 according GPCC data). The average summer rainfall in the Russian part of the basin is recovering since 2015 (see Figure 9a,b, gray lines).

In the Mongolian part of the water basin, the gradation for the dry and rainy seasons was less pronounced. Abnormally low rainfall occurred in 2014 and 2015 (see Figure 9c,d). In addition, note that there was a significant difference in the results obtained using the CRU and GPCC datasets (Figure 9c,d), which was not observed for annual variability in the Russian part of the basin (please compare Figure 9a,b).
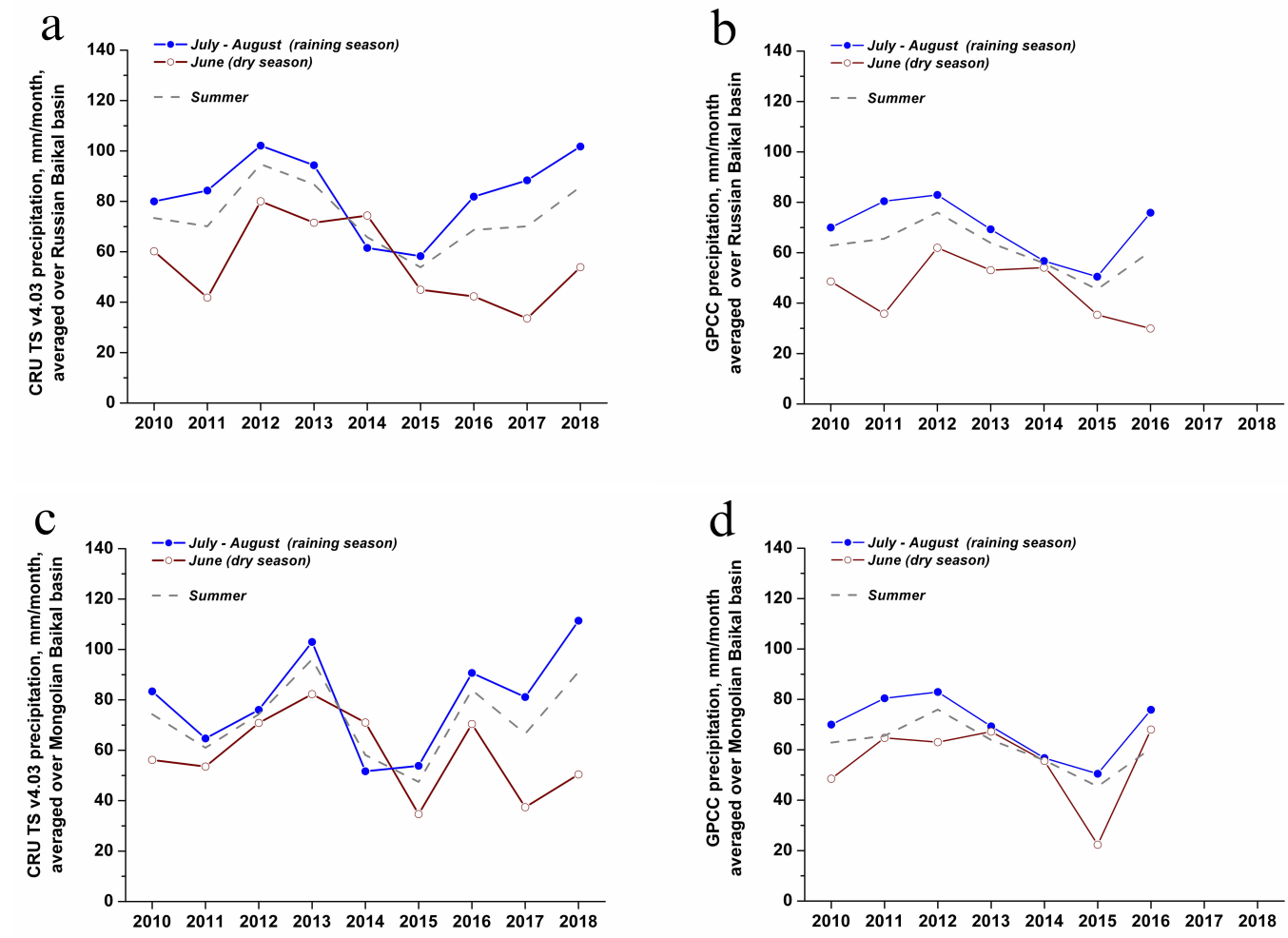

Figure 9. The monthly total precipitation ( $\mathrm{mm} / \mathrm{month})$, spatially averaged over the territory of the Russian $(\mathbf{a}, \mathbf{b})$ and the Mongolian parts $(\mathbf{c}, \mathbf{d})$ of the Baikal basin, and temporally averaged over the wet period (July-August, blue lines), the dry period (June, brown lines), and the whole summer (June-August, gray dashed lines). The CRU TS precipitation datasets (2010-2018) are presented in panels (a,c); the GPCC precipitation datasets (2010-2016) are presented in panels (b,d).

\subsection{Aridity Index and Potential Evaporation in the Basin of the Lake Baikal}

In addition to rainfall, local climate changes can be characterized using the potential evaporation and the aridity index. Below, the spatial distributions of the aridity index (Ia) are analyzed. In this study, the aridity indexes were calculated using the CRU TS dataset. The Ia spatial distributions in the relatively wet summer of 2010 and in the abnormally dry summer of 2015 are presented in Figure 10. From this figure, it is clearly visible that, in 2015, the large areas nearby the Lake Baikal were subjected to drought (see yellow area, Figure 10). 

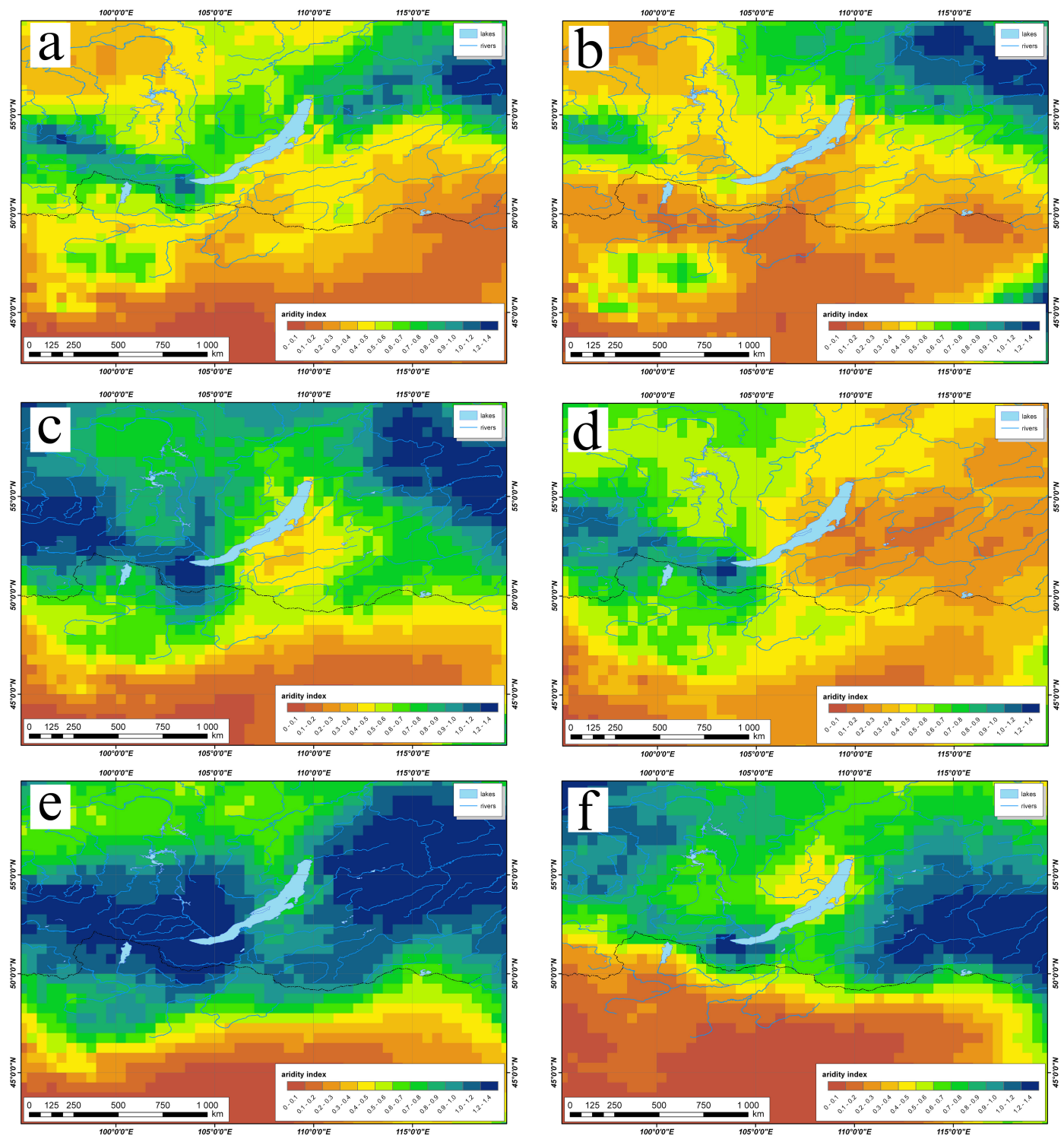

Figure 10. The comparison between the spatial distribution of aridity index in the relatively wet 2010 summer (a,c,e) and in the abnormally dry 2015 summer $(\mathbf{b}, \mathbf{d}, \mathbf{f})$. Panels $(\mathbf{a}, \mathbf{b})$ correspond to June, $(\mathbf{c}, \mathbf{d})$ correspond to July, and $(\mathbf{e}, \mathbf{f})$ correspond to August. The aridity index was calculated based on the CRU TS climatic dataset.

Furthermore, the aridity indexes averaged over the Russian and Mongolian parts of the Baikal water basin for the rainy period (July-August, blue lines) and for the dry period (June, brown lines) are presented in Figure 11. As a whole, since 2015, the drought period was replaced by a trend to restore the water balance. In the Russian part of the basin, the aridity index in 2012, 2013, and 2018 in the wet period exceeded 1 , that is, the amount of rainfall was greater than potential evaporation. In July, in the Russian part of the basin, the aridity index trend remained negative until 2018. In the Mongolian part, after 2015, the water balance began showing a restoration trend; in 2018, the aridity index in the rainy season reached a value equal to 1 . 

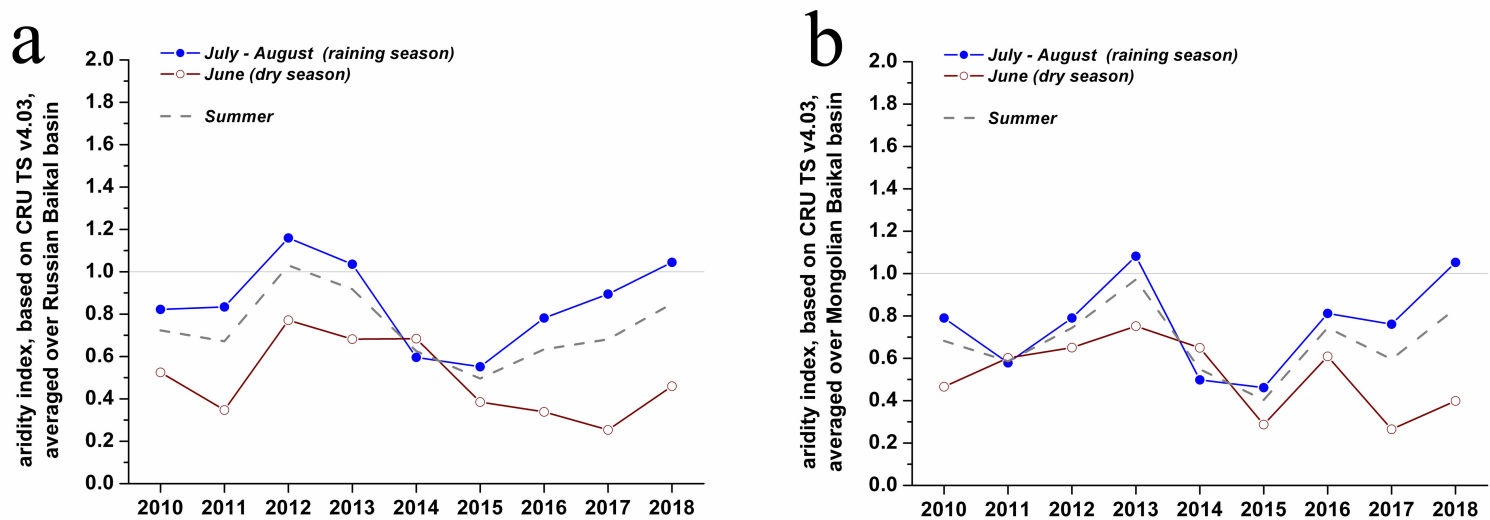

Figure 11. The aridity indexes, spatial averaged over the territory of the Russian (a) and the Mongolian parts (b) of the Baikal basin, for the wet period (July-August, blue lines), dry period (June, brown lines), and the whole summer (June-August, gray dashed lines). The aridity index was calculated using the CRU TS climatic dataset.

4.4. Relative Contribution of the Mongolian and Russian parts of the Baikal Basin in Precipitation and Aridity Indexes

The answer to the following rather prosaic question turned out to be very interesting: What are the relative contributions to the precipitation and aridity indexes of the Mongolian and Russian parts of the Baikal basin? The ratios of total precipitation during the rainy period (July-August) in the Russian and Mongolian parts of the basin are presented in Figure 12. Both the CRU TS and GPS datasets showed quasi-two-year relationship oscillations throughout the study range with negative trends. Note that the quasi-two-year oscillations are not clearly visible on the distributions presented in Figure 9.

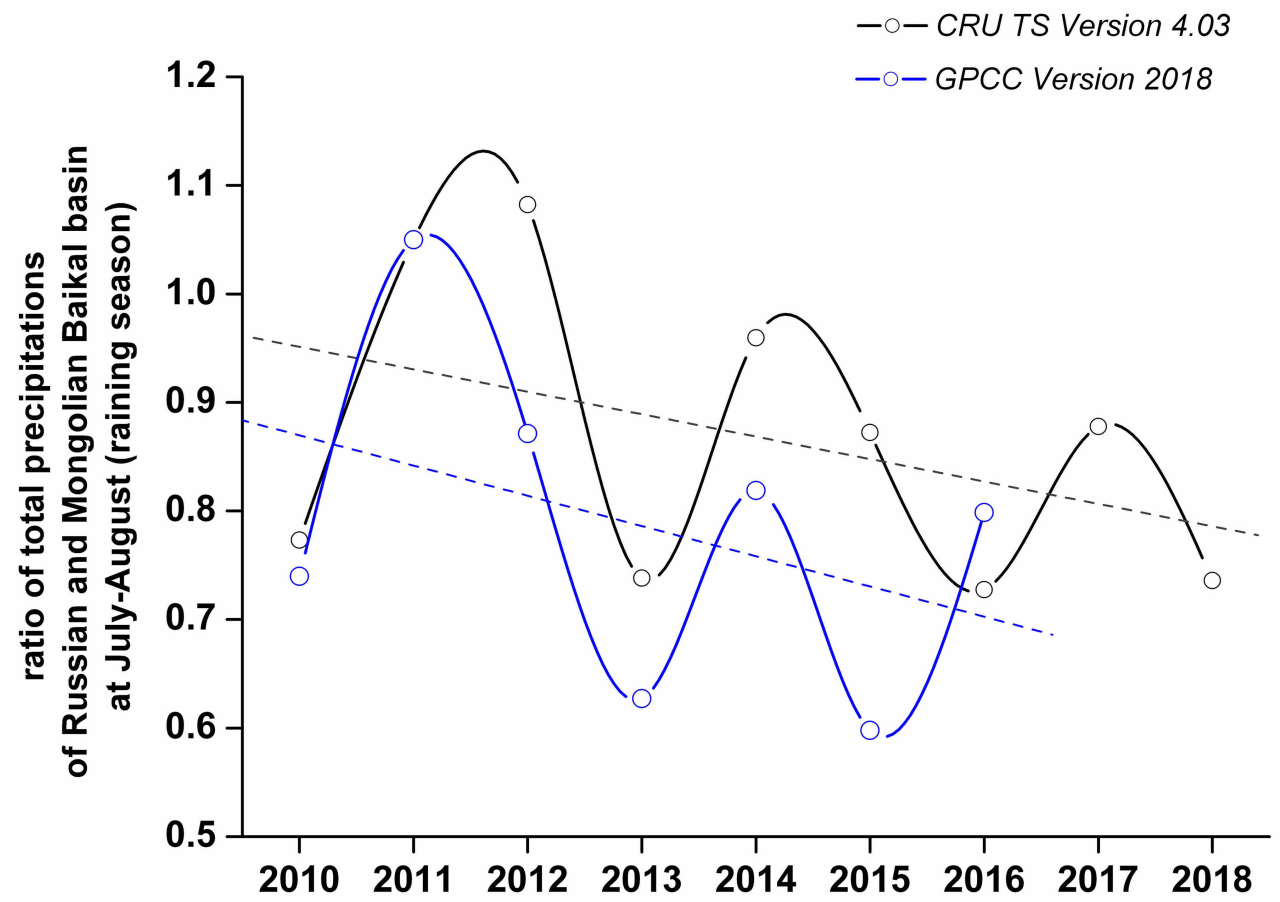

Figure 12. The ratios of total precipitations, in the Russian and in the Mongolian parts of the Baikal basin, during the wet period (July-August) are presented. The calculations were done using the CRU TS (black line) and by the GPCC (blue line) precipitation datasets. 
The quasi-two-year oscillations in the aridity index ratios are also recorded; however, in this case, the trends were approximately zero. The amplitude of oscillations decreased in the rainy season. Therefore, the quasi-two year oscillations of aridity index which were recorded at the arid-semiarid-humid boundaries were not unusual.

Previously, the quasi-two-year and 11-year oscillations were repeatedly recorded in the climatic temperature trend and in the distribution of chemical compounds in the troposphere. Therefore, we simply highlight that, at present, there is no known physical mechanism which could explain the relationship between the quasi two-year, 11-year, and other climatic variations with celestial mechanics. Note that the presence of the planetary frequencies, both in the climatic data and in the solar activity, horrifies modern astrophysicists.

\section{Analysis of Wildfire Situations}

\subsection{The Temporal and Spatial Distributions of Hotspots}

In this study, the spatial and temporal distributions of wildfires according to MODIS infrared channels throughout the summer period of 2010-2018 were investigated. The number of hotspots in the Russian part of the Baikal basin significantly exceeded the number of fires in the Mongolian part. Therefore, in our research, the main attention was focused on the study of the dynamics in the number of wildfires in the Russian part of basin.

Statistical data on the hotspots number are presented in Table 2. Usually, in the rainy season (July-August) the number of hotspots sharply decreases. However, in 2014 and 2015, this was not observed. Thus, the number of hotspots in August 2015 was 19.56 times higher than that in June.

Table 2. The number of MCD12ML hotspots (active fires, AF), established with more than $75 \%$ confidence located in the Russian part of the Baikal basin, during the climatic dry period (June) and climatic wet period (July-August). The abnormal increase in wildfire amount in the climatic wet period is highlighted by gray color.

\begin{tabular}{ccccc}
\hline \multirow{2}{*}{ Year } & \multicolumn{4}{c}{ Quantity of Hotspots, MCD14ML (Active Fires, AF) } \\
\cline { 2 - 5 } & June & July & August & July-August Rainy Season \\
\hline 2010 & 264 & 160 & 13 & 173 \\
2011 & 1169 & 159 & 19 & 178 \\
2012 & 7 & 0 & 4 & 4 \\
2013 & 118 & 7 & 10 & 17 \\
2014 & 157 & 236 & 209 & 445 \\
2015 & 673 & 2297 & 13164 & 15461 \\
2016 & 572 & 469 & 18 & 487 \\
2017 & 849 & 298 & 132 & 430 \\
2018 & 27 & 5 & 7 & 12 \\
\hline
\end{tabular}

Thus, in general, the spatial hotspot distribution corresponds to aridity zones, but it cannot explain the 20-fold increase in the number of hotspots in the area of the Russian part of the Lake Baikal water basin. Such an abnormal increase in the number of wildfires and their localizations indicate the anthropogenic nature of wildfires. However, most hotspot locations were away from settlements, roads, and loggings, in difficult-to-access mountainous areas, as well as in the low-inhabited areas of Siberia.

The spatial hotspot distributions in July and August are presented using the examples of rainy 2010 and abnormally dry 2015 (see Figure 13a,b, respectively). Note that major hotspots in 2015 were localized near the coast of Lake Baikal. However, according to the CRU TS and GPCC precipitation data given in the present study, a minimum amount of rainfall was observed in the steppes to the south of Lake Baikal. 

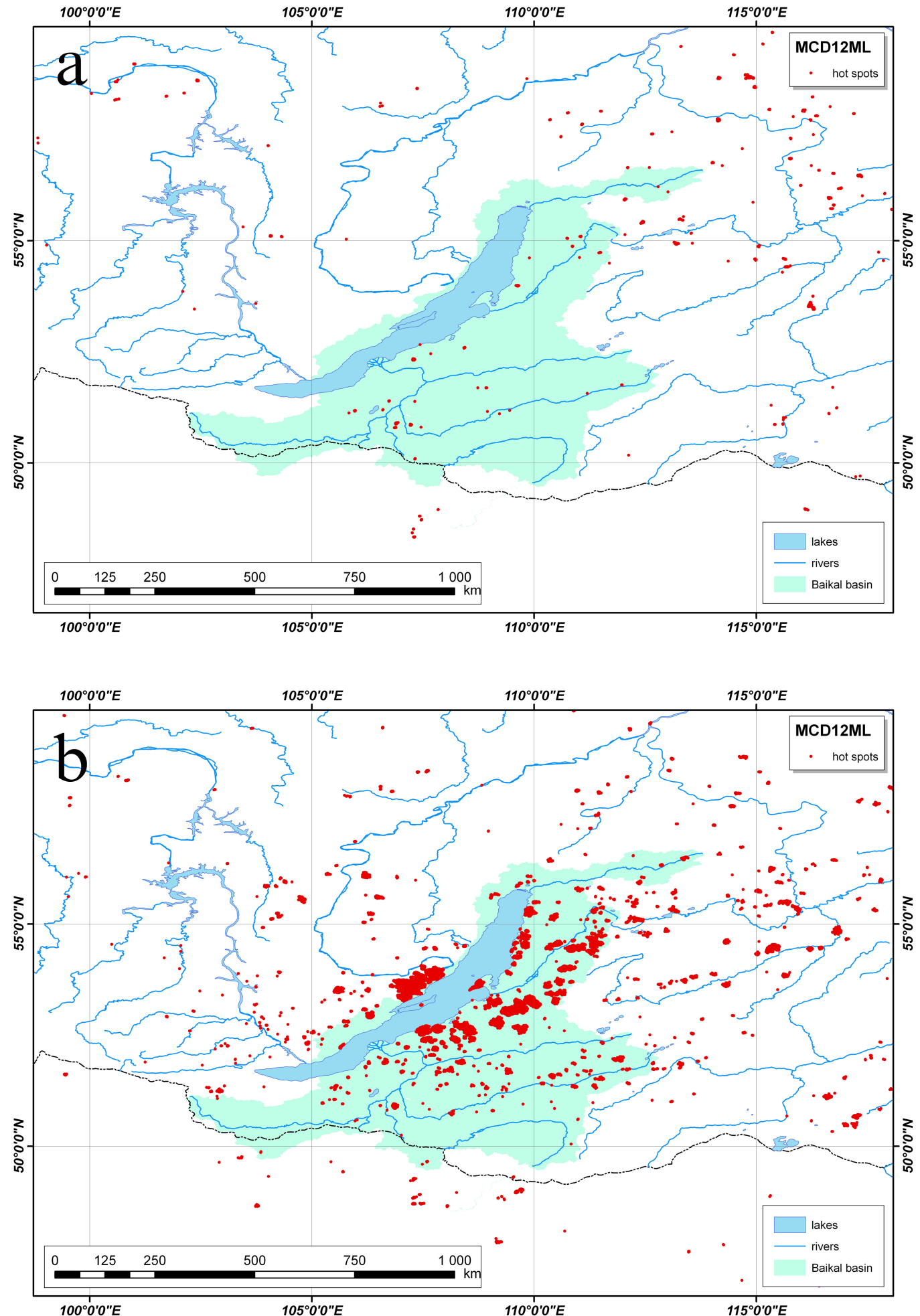

Figure 13. The comparison between spatial distributions of July-August wildfires (MCD14ML active fires, AF) in the relatively wet 2010 summer (a) and in the abnormally dry 2015 summer (b) is presented.

\subsection{The Spatial Distributions of Burned Areas}

Furthermore, in this study, the spatial distribution of the areas affected by wildfires was analyzed. The total area damaged by fires during the summer from 2010 to 2018 is shown in red in Figure 14. These burned area maps were obtained using the MCD64A1 product of MODIS spectrometers. 
Sometimes, ignitions in sparsely populated regions are explained by burning during illegal logging. As it can be seen from the Figure 14, the wildfires did not only occur in forest zones; thus, the origin of multiple ignitions in the sparsely populated areas cannot be explained by burning after illegal logging. Most hotspot locations were away from settlements, roads, and loggings, in difficult-to-access mountainous areas, as well as in the low-inhabited areas of Siberia.

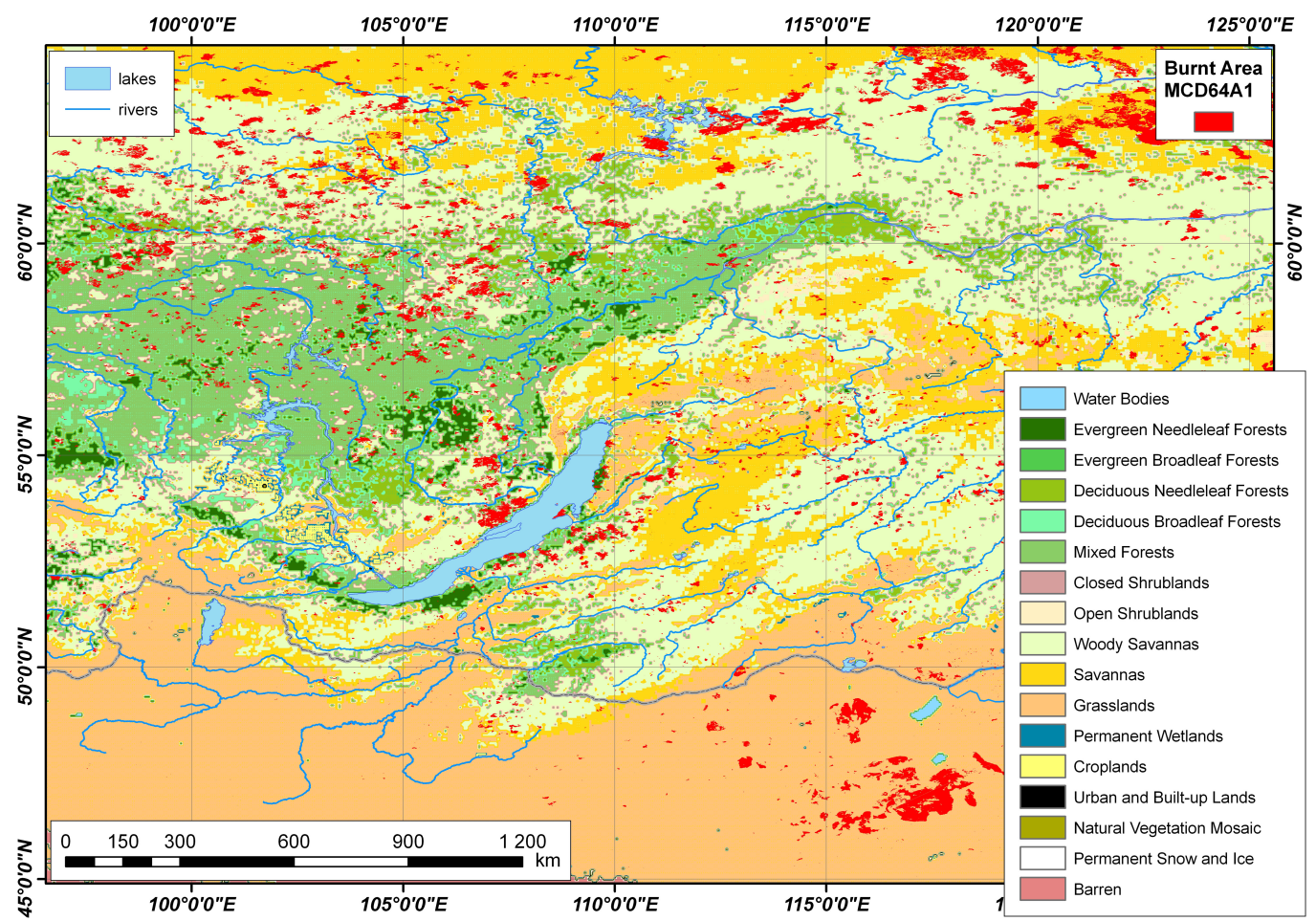

Figure 14. The total burned area, damaged by wildfires from June-August in 2010-2018, is shown. The burned area was obtained from the MCD64A1 (burned area, BA) dataset. The MCD12C1 land-cover map (2010) is presented as a background.

\subsection{Dry Lightning and Pyrocumulus Lightning as the Reasons for Ignitions}

We end by discussing the reasons for ignitions. There are two basic mechanisms of ignition, namely, dry lighting and pyrogenic lighting. Below, we consider both mechanisms.

Firstly, we consider the mechanism of dry lighting. The frequency of non-anthropogenic ignitions significantly exceeds the frequency of the dry thunderstorms, which are usually observed at temperatures above $40{ }^{\circ} \mathrm{C}$, with low levels of rainfall, traditionally less than $2.5 \mathrm{~mm}$, when the water droplets fall through the driest air from the relatively highest cloud base. Dry thunderstorms are characterized by midlevel $(850-500 \mathrm{hPa})$ instability, low-level $(850 \mathrm{hPa})$ dewpoint depressions, and certain warm-season synoptic patterns. Most significant dry thunderstorm events that produce thousands of cloud-ground (CG) strikes and hundreds of wildfires occur in the western United States in the area between the Pacific coast and the Rocky Mountains in the North American warm season, when monsoonal moisture comes from the Gulfs of California or Mexico [53]. The CG dry strikes are generated in the elevated moisture plume at $700-500 \mathrm{hPa}$ and have ordinary negative polarity. Details regarding forecast predictions of dry thunderstorms can be found in References [53-56].

Thus, the mandatory attribute of dry thunderstorms has to be presented in the satellite images as frontal opaque middle-troposphere clouds. The example of unusual spatial distribution of the wildfires and thermal anomalies around the Baikal on 22 August 2015, is presented in Figure 15. The MODIS corrected reflectance imagery with RGB true color (red $=$ band 1 , green $=$ band 4 , blue $=$ band 3 ) is presented on the Earth background image. However, frontal opaque middle-troposphere clouds are absent in Figure 15; nearby Lake Baikal, only smoke plumes from wildfires are clearly visible. 


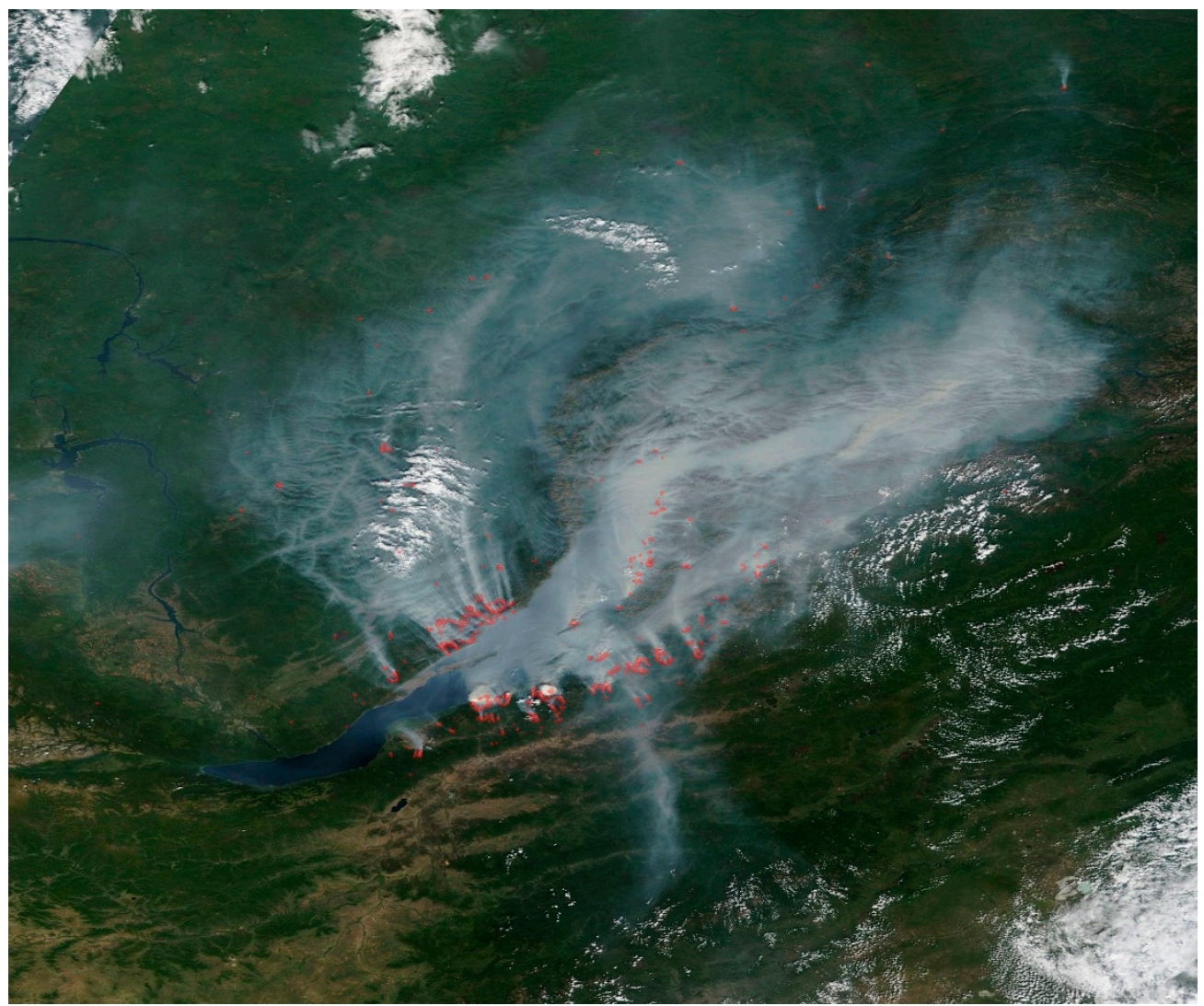

Figure 15. The image of fires and thermal anomalies (red) created by the Terra and Aqua satellite products (MOD14, MYD14, red color) on 22 August 2015, obtained using the World View of Global Imagery Browse Services (GIBS), is presented. The MODIS corrected reflectance imagery (true color: red $=$ Band 1, green $=$ Band 4 , blue $=$ Band 3 ) is presented as a background satellite image. The smoke from the wildfires are clearly visible.

In addition to dry lightning, there is another mechanism, which is sometimes called pyrocumulus lightning. Strong and deep convection can occur within a wildfire column. This convection, known as pyroconvection, affects weather conditions near the fire and at higher levels in the troposphere. Moreover, pyroconvection is sometimes strong enough to inject wildfire smoke into the stratosphere. The condensation of moisture in the fire column can release latent heat and lead to formed smoke clouds known as pyrocumulus (pyroCu) or pyrocumulonimbus (pyroCb). On occasion, these clouds produce electric charges and pyrogenic lightning. More details on pyroconvection and pyrogenic lightning can be found, for example, in References [57-64] and the numerous references therein.

Positive CG flashes typically contain a single return stroke, which exhibits the greatest peak currents (sometimes $\sim 300 \mathrm{kA}$ ) and produces the largest charge transfers to ground [57]. Rosenfeld et al. [59] also noted that pyroCb strikes are characterized by a high density of high-intensity (in several cases more than $100 \mathrm{kA}$ ), positive lightning, while most non-pyro $\mathrm{Cb}$ lightning strikes produced in ambient clouds have negative polarity. Furthermore, in Reference [59], it was assumed that the positive lightning induced by smoke ignited new fires that emitted even more smoke, thus driving a positive feedback loop. Rudlosky and Fuelberg [60] presented that heat and smoke of very near preexisting wildfires are the key ingredients in producing positive polarity cloud-ground storms that often ignite subsequent wildfires. McRae et al. [62] suggested that the dry pyroCb thunderstorms that passed over the region ignited new fires by means of lightning strikes.

However, some statements in the above studies cause some confusion. Why is pyrogenic lightning usually observed in the upper troposphere and in the stratosphere but not in the middle and low troposphere? Note that puroCb aerosol charging and lightning look like the electrification processes 
in volcanic plumes. Details of volcanic plume charging can be found in References [65-68]. Thus, it is easy to find an answer to the above question. We assume that triboelectric (frictional) charging within the puroCb plume is a major electrical charging mechanism for wildfire aerosol. The electric charges are generated in the atmospheric layer at the tropopause due to the friction of aerosol granules at strong horizontal wind shift.

The strong convective activity over hotspots leads to the plume raising, and then the plume separates in the different charged layers due to gravitation. In the lower level, the coarse wildfire aerosol is positively charged, and the higher finer aerosol layer is negatively charged. The temperature gradient nearby the tropopause prevents the aerosol from falling down. Therefore, the puroCb plume gets the characteristic form of a mushroom cloud. The positive puroCb CG strike means that a significant amount of negative charge, usually called a negative upward leader, moves from the ground to the clouds. Sometimes, a positive CG strike consists of two strikes that move toward each other, named a negative upward leader and a downward positive leader [57]. Thus, pyrogenic strikes occur between the tropopause and an earth surface only in the presence of huge quantity of wildfire aerosol that is thrown up over the tropopause in the stratosphere. The necessary aerosol quantity for pyrogenic strikes needs further study.

We return again to the consideration of Figure 15. It is clearly visible that wildfire plumes moved below the cumulus and they did not form enough opaque aerosol wildfire clouds at the tropopause. Thus, in our case, pyrogenic lightning cannot be a source of abnormal ignitions in the low-inhabited areas of Siberia.

In summary, we show that the reason for ignitions in the low-inhabited areas are probably not the result of dry lightning (dry thunderstorms) or pyrogenic lightning. The absence of dense frontal rain clouds in the middle troposphere and wildfire aerosol clouds at the troposphere-stratosphere boundary is the basis for this conclusion. In this situation, it is possible to surmise that, in clear sky conditions, the ignitions are probably the result of hypothetical spacecraft impact. Therefore, we conclude that such ignitions in the low-inhabited areas of Siberia are due to dry thunderstorms, pyrocumulus lightning, or spacecraft impact.

\section{Conclusions}

In this study, the vegetation changes in the area of the Russian part of Lake Baikal basin during the period 2010-2018 were investigated using MCD12C1 land cover.

The decline in swamp areas began in 2012 and continued until 2015, before partially recovering during the heavy rain season in 2018. Over the entire period between 2010 and 2018, the area covered by forests did not exceed $20.3 \%$ of the total part of the Baikal basin taken into account in this work. Deforestation began in 2013 and continued until 2017. The forest area over 2010-2018 decreased by $2.45 \%$ of the total studying area or by $12.1 \%$ of the area covered by forest in 2013 . However, in the same period, an increase (3.8\% of the total studying area) in areas of steppes and forest-steppes was observed. Since 2013, with a decrease in rainfall, a decrease in the areas occupied by forests and an increase in areas of steppes and forest-steppes occurred. It was shown that the vegetation changes seem to follow both climatic warming and changes in the aridity index.

The analysis of climatic changes in the Baikal water basin was done using CRU TS and GPCC climatic datasets. The spatial and temporal distributions of summer rainfalls and aridity indexes in the Lake Baikal basin were carried out. The aridity indexes averaged over the Russian and Mongolian parts of the Baikal water basin for the rainy season (July-August) and for the relatively dry period (June) were calculated. In the Russian part of the Baikal basin, since 2015, the drought was replaced by a trend of restoring the water balance. In the dry season, in the Russian part of the basin, the aridity index trend remained negative until 2018. In the Mongolian part, the water balance began to exhibit restoration only after 2015; in 2018, the aridity index in the rainy season in this part of the basin reached a value equal to 1 . 
Furthermore, the relative contribution of the Mongolian and Russian parts of the Baikal basin in terms of precipitation and aridity index was investigated. The quasi-two-year oscillations in the aridity index and precipitation ratios were recorded. It is shown that the interannual variations of precipitation and aridity changes were determined by the variability of the global circulation of air masses saturated with water vapor.

The direct correlation between the changes in vegetation and aridity indexes was not traced. As it is known, vegetation has adaptive properties; thus, when the climate changes, the vegetation tries to adapt to such changes. Therefore, changes in vegetation occur later with respect to changes in both rainfall and aridity of an area. On the other hand, the response in vegetation to the increase in precipitation and restoration of the aridity level either occurs with a great delay or is not observed at all during the observational time interval. This particularly concerns the tree-like types of vegetation, since the restoration of forests happens slowly.

In the last part of this study, the MCD64A1 (burned area) and MCD14ML (active fires) MODIS products were used for investigation of the spatial distributions of wildfires. The spatial hotspot distributions and burned areas in general correspond to aridity zones, but they cannot explain the 20-fold increase in the number of wildfires in the Russian part of the Lake Baikal basin. Most hotspot locations were away from settlements, roads, and loggings, in difficult-to-access mountainous areas, as well as in the low-inhabited areas of Siberia. We assume that such ignitions in the low-inhabited areas of Siberia are due to dry thunderstorms, pyrocumulus lightning, or remote impact from spacecraft.

Supplementary Materials: The following are available online at http://www.mdpi.com/2225-1154/8/4/57/s1: Table S1. The MCD12C1 International Geosphere-Biosphere Program (IGBP) legend and class descriptions.

Funding: This research was funded by the Russian Foundation for Basic Research (Grant Nos. RFBR 17-29-05102).

Acknowledgments: We would like to thank the University of East Angelia, UK, for providing valuable CRU TS Version 4.03 climate datasets.

Conflicts of Interest: The authors declare no conflicts of interest.

\section{References}

1. Sinyukovich, V.N.; Sizova, L.N.; Shimaraev, M.N.; Kurbatova, N.N. Characteristics of Current Changes in Water Inflow Into Lake Baikal. Geogr. Nat. Resour. 2013, 34, 350-355. [CrossRef]

2. Törnqvist, R.; Jarsjö, J.; Pietron, J.; Bring, A.; Rogberg, P.; Asokan, S.M.; Destouni, G. Evolution of the hydro-climate system in the Lake Baikal basin. J. Hydrol. 2014, 519, 1953-1962. [CrossRef]

3. Dabaeva, D.B.; Tsydypov, B.Z.; Ayurzhanaev, A.A.; Andreev, S.G.; Garmaev, Y.Z. Peculiarities of Lake Baikal water level regime. IOP Conf. Ser. Earth Environ. Sci. 2016, 48, 012014. [CrossRef]

4. Frolova, N.L.; Belyakova, P.A.; Grigor'ev, V.Y.; Sazonov, A.A.; Zotov, L.V. Many-Year Variations of River Runoff in the Selenga Basin. Water Resour. 2017, 44, 359-371. [CrossRef]

5. Frolova, N.L.; Belyakova, P.A.; Grigoriev, V.Y.; Sazonov, A.A.; Zotov, L.V.; Jarsjö, J. Runoff fluctuations in the Selenga River Basin. Reg. Environ. Chang. 2017, 17, 1965-1976. [CrossRef]

6. Sinyukovich, V.N.; Chernyshov, M.S. Transformation of estimated characteristics of the annual and maximal runoff in the major tributaries of Lake Baikal. Water Resour. 2017, 44, 372-379. [CrossRef]

7. Dobrovol'skii, S.G. Year-to-year and many-year river runoff variations in Baikal Drainage Basin. Water Resour. 2017, 44, 347-358. [CrossRef]

8. Dorjsuren, B.; Yan, D.; Wang, H.; Chonokhuu, S.; Enkhbold, A.; Yiran, X.; Girma, A.; Gedefaw, M.; Abiyu, A. Observed Trends of Climate and River Discharge in Mongolia's Selenga Sub-Basin of the Lake Baikal Basin. Water Resour. 2018, 10, 1436. [CrossRef]

9. Sinyukovich, V.N.; Chernyshov, M.S. Water regime of lake Baikal under conditions of climate change and anthropogenic influence. Quat. Int. 2019, 524, 93-101. [CrossRef]

10. Namzalov, B.B. For question's about of relict in the flora and vegetation of steppe ecosystems of the Baikal Siberia (In Russian, Abstract in English only). Plant Life Asian Russ. 2012, No2, 94-100.

11. Dulepova, N.A.; Korolyuk, A.Y. Psammophyte vegetation of the Selenga river basin (Republic of Buryatia). Veg. Russ. St. Petersburg 2015, 27, 78-95. [CrossRef] 
12. Namzalov, B.B.; Chimitov, D.G.; Imetkhenova, O.V.; M.B-Namzalov, T.; Banaeva, S.C. Rare and relict species in flora of the Selenga Mountains (Western Transbaikalia). Plant Life Asian Russ. 2016, No1, 75-79. (In Russian, Abstract in English Only)

13. Gunin, P.D.; Bazha, S.N.; Baldanov, B.T.; Baskhaeva, T.G.; Drobyshev, Y.I.; Dugarjav, C.; Kontsov, S.V.; Ubugunov, V.L.; Ubugunova, V.I.; Khadbaatar, S.; et al. Deforestation is one of the most major environmental problems of the lake Baikal basin. Ekosist. Ekol. Din. (Ecosyst. Ecol. Dyn.) 2017, 1, 38-39. (In Russian)

14. Kharuk, V.I.; Im, S.T.; Petrov, I.A.; Yagunov, M.N. Decline of dark coniferous stands in Baikal Region. Contemp. Probl. Ecol. 2016, 9, 617-625. [CrossRef]

15. Kharuk, V.I.; Im, S.T.; Petrov, I.A.; Golyukov, A.S.; Ranson, K.J.; Yagunov, M.N. Climate-induced mortality of Siberian pine and fir in the Lake Baikal Watershed, Siberia. For. Ecol. Manag. 2017, 384, 191-199. [CrossRef] [PubMed]

16. Kharuk, V.; Ranson, K.; Oskorbin, P.; Im, S.; Dvinskaya, M. Climate induced birch mortality in Trans-Baikal lake region, Siberia. For. Ecol. Manag. 2013, 289, 385-392. [CrossRef]

17. Karthe, D.; Chalov, S.; Kasimov, N.; Kappas, M. Water and Environment in the SelengaBaikal Basin: International Research Cooperation for an Ecoregion of Global Relevance; ibidem-Verlag: Stuttgart, Germany, 2015.

18. Berezhnykh, T.V.; Marchenko, O.Y.; Abasov, N.V.; Mordvinov, V.I. Changes in the Summertime Atmospheric Circulation Over East Asia and Formation of Long-Lasting Low-Water Periods Within the Selenga River Basin. Geogr. Nat. Resour. 2012, 33, 223-229. [CrossRef]

19. Lamchin, M.; Lee, W.-K.; Jeon, S.W.; Wang, S.W.; Lim, C.H.; Song, C.; Sung, M. Long-term trend and correlation between vegetation greenness and climate variables in Asia based on satellite data. Sci. Total Environ. 2018, 618, 1089-1095. [CrossRef]

20. Wang, G.; Wang, P.; Wang, T.-Y.; Zhang, Y.-C.; Yu, J.-J.; Ma, N.; Frolova, N.L.; Liu, C.-M. Contrasting Changes in Vegetation Growth due to Different Climate Forcings over the Last Three Decades in the Selenga-Baikal Basin. Remote Sens. Environ. 2019, 11, 426. [CrossRef]

21. Friedl, M.A.; Sulla-Menashe, D.; Tan, B.; Schneider, A.; Ramankutty, N.; Sibley, A.; Huang, X. MODIS Collection 5 global land cover: Algorithm refinements and characterization of new datasets. Remote Sens. Environ. 2010, 114, 168-182. [CrossRef]

22. Sulla-Menashe, D.; Gray, J.M.; Abercrombie, S.P.; Friedl, M.A. Hierarchical mapping of annual global land cover 2001 to present: The MODIS collection 6 land cover product. Remote Sens. Environ. 2019, 222, $183-194$. [CrossRef]

23. Sulla-Menashe, D.; Friedl, M.A. User Guide to Collection 6 MODIS Land Cover (MCD12Q1 and MCD12C1) Product. 2018. Available online: https://lpdaac.usgs.gov/documents/101/MCD12_User_Guide_V6.pdf (accessed on 15 April 2020). [CrossRef]

24. Safronov, A.N.; Fokeeva, E.V.; Rakitin, V.S.; Yurganov, L.N.; Grechko, E.I. Carbon monoxide emissions in summer 2010 in the central part of the Russian Plain and estimation of their uncertainties with the use of different land-cover maps. Izv. Atmos. Ocean. Phys. 2012, 48, 925-940. [CrossRef]

25. Safronov, A.N.; Fokeeva, E.V.; Rakitin, V.S.; Grechko, E.I.; Shumsky, R.A. Severe Wildfires Near Moscow, Russia in 2010: Modeling of Carbon Monoxide Pollution and Comparisons with Observations. Remote Sens. Environ. 2015, 7, 395-429. [CrossRef]

26. Bartalev, S.A.; Ershov, D.V.; Isaev, A.S.; Potapov, P.V.; Turubanova, S.A.; Yaroshenko, A.Y. Russia's Forests-Dominating Forest Types and Their Canopy Density, Moscow, Greenpeace Russia and RAS Centre for Forest Ecology and Productivity, (Map, scale 1:14:000:000), 2004. Available online: http: //forestforum.ru/info/pictures/engmap.pdf (accessed on 15 April 2020).

27. Bartalev, S.A.; Belward, A.S.; Erchov, D.V.; Isaev, A.S. A new SPOT4-VEGETATION derived land cover map of Northern Eurasia. Int. J. Remote Sens. 2003, 24, 1977-1982. [CrossRef]

28. Hüttich, C.; Herold, M.; Schmullius, C.; Egorov, V.; Bartalev, S.A. Indicators of Northern Eurasia's land cover change trends from SPOT-VEGETATION time series analysis 1998-2005. Int. J. Remote Sens. 2007, 28, 4199-4206. [CrossRef]

29. Bartalev, S.A.; Egorov, V.A.; Ershov, D.V.; Isaev, A.S.; Loupian, E.A.; Plotnikov, D.E.; Uvarov, I.A. Mapping of Russia's vegetation cover using MODIS satellite spectroradiometer data. Curr. Probl. Remote Sens. Earth Space 2011, 8, 285-302. (In Russian) 
30. Bartalev, S.A.; Egorov, V.A.; Zharko, V.O.; Loupian, E.A.; Plotnikov, D.E.; Khvostikov, S.A. Current state and development prospects of satellite mapping methods of Russia's vegetation cover. Curr. Probl. Remote Sens. Earth Space 2015, 12, 203-221. (In Russian)

31. Bartalev, S.A.; Plotnikov, D.E.; Loupian, E.A. Mapping of arable land in Russia using multi-year time series of MODIS data and the LAGMA classification technique. Remote Sens. Lett. 2016, 7, 269-278. [CrossRef]

32. Egorov, V.A.; Bartalev, S.A.; Kolbudaev, P.A.; Plotnikov, D.E.; Khvostikov, S.A. Land cover map of Russia derived from Proba-V satellite data. Curr. Probl. Remote Sens. Earth Space 2018, 15, 282-286. [CrossRef]

33. Harris, I.; Jones, P.D.; Osborn, T.J.; Lister, D.H. Updated high-resolution grids of monthly climatic observations - the CRU TS3.10 Dataset. Int. J. Climatol. 2014, 34, 623-642. [CrossRef]

34. CRU-UEA: Dataset CRU TS4.03. Available online: https://crudata.uea.ac.uk/cru/data/hrg/cru_ts_4.03/cruts. 1905011326.v4.03/ (accessed on 15 April 2020).

35. Yang, J.; Ding, Y.; Chen, R.; Liu, L. Fluctuations of the Semi-Arid Zone in China, and Consequences for Society. Clim. Chang. 2005, 72, 171-188. [CrossRef]

36. Kulikov, A.I.; Tsydypov, B.Z.; Sodnomov, B.V.; Gyninova, A.B.; Wang, J. Land Aridization in the Context of Global Warming-A Case Study of Transbaikalia. J. Resour. Ecol. 2017, 8, 141-147. [CrossRef]

37. Datasets: GPCCDWD. Available online: https://opendata.dwd.de/climate_environment/GPCC/html/fulldatamonthly_v2018_doi_download.html (accessed on 15 April 2020).

38. Schneider, U.; Becker, A.; Finger, P.; Meyer-Christoffer, A.; Ziese, M. GPCC Full Data Monthly Product Version 2018 at 0.5 : Monthly Land-Surface Precipitation from Rain-Gauges Built on GTS-based and Historical Data; Deutscher Wetterdienst: Offenbach am Main, Hessen, Germany, 2018. [CrossRef]

39. Schneider, U.; Finger, P.; Meyer-Christoffer, A.; Ziese, M.; Becker, A. Global Precipitation Analysis Products of the GPCC//Global Precipitation Climatology Centre (GPCC), Deutscher Wetterdienst, Offenbach a. M., Germany. 2018. Available online: https://opendata.dwd.de/climate_environment/GPCC/PDF/GPCC_intro_ products_v2018.pdf (accessed on 15 April 2020).

40. Sun, Q.; Miao, C.; Duan, Q.; Ashouri, H.; Sorooshian, S.; Hsu, K.-L. A review of global precipitation data sets: Data sources, estimation, and intercomparisons. Rev. Geophys. 2018, 56, 79-107. [CrossRef]

41. Giglio, L.; Csiszar, I.; Justice, C.O. Global distribution and seasonality of active fires as observed with the Terra and Aqua MODIS sensors. J. Geophys. Res. 2006, 111, G02016. [CrossRef]

42. Giglio, L.; Schroeder, W.; Justice, C.O. The collection 6 MODIS active fire detection algorithm and fire products. Remote Sens. Environ. 2016, 178, 31-41. [CrossRef]

43. Giglio, L.; Schroeder, W.; Hall, J.V.; Justice, C.O. MODIS Collection 6 Active Fire Product User's Guide, Revision B. 2018. Available online: http://modis-fire.umd.edu/files/MODIS_C6_Fire_User_Guide_B.pdf (accessed on 25 October 2019).

44. Roy, D.P.; Giglio, L.; Kendall, J.D.; Justice, C.O. A multitemporal active-fire based burn scar detection algorithm. Int. J. Remote Sens. 1999, 20, 1031-1038. [CrossRef]

45. Giglio, L.; Boschetti, L.; Roy, D.; Hoffmann, A.A.; Humber, M.; Hall, J.V. Collection 6 MODIS Burned Area Product User's Guide Version 1.2. 2018. Available online: http://modis-fire.umd.edu/files/MODIS_C6_BA_ User_Guide_1.2.pdf (accessed on 15 April 2020).

46. Giglio, L.; Boschetti, L.; Roy, D.P.; Humber, M.L.; Justice, C.O. The Collection 6 MODIS burned area mapping algorithm and product. Remote Sens. Environ. 2018, 217, 72-85. [CrossRef]

47. ESRI ArcInfo Information. Available online: http://www.esri.com/software/arcgis/arcinfo/index.html (accessed on 15 April 2020).

48. DeLorme Publishing Company and ESRI. World Water Bodies, 2013; ESRI: Redlands, CA, USA, 2014; Available online: http://sandbox.idre.ucla.edu/mapshare/data/world/data/hydropolys.zip (accessed on 15 April 2020).

49. Ilyicheva, Y.A.; Korytny, L.M.; Pavlov, M.V. The river network of the Selenga Delta at present. Tomsk State Univ. J. 2014, 380, 190-194. [CrossRef]

50. Korytny, L.M.; Il'icheva, E.A.; Pavlov, M.V.; Amosova, I.Y. Hydrologo-Morphological Approach to Regionalizationof the Selenga River Basin. Geogr. Nat. Resour. 2012, 33, 212-217. [CrossRef]

51. Ilyicheva, E.I.; Gagarinova, O.V.; Pavlov, M.V. Hydrologo-Geomorphological Analysis of Landscape Formation within the Selenga River Delta. Geogr. Nat. Resour. 2015, 36, 263-270. [CrossRef]

52. Kasimov, N.; Karthe, D.; Chalov, S. Environmental change in the Selenga River-Lake Baikal Basin. Reg. Environ. Chang. 2017, 17, 1945-1949. [CrossRef] 
53. Nauslar, N.J.; Kaplan, M.L.; Wallmann, J.; Brown, T.J. A forecast procedure for dry thunderstorms. J. Oper. Meteorol. 2013, 1, 200-214. [CrossRef]

54. Rorig, M.L.; Ferguson, S.A. Characteristics of lightning and wildland fire ignition in the Pacific Northwest. J. Appl. Meteorol. 1999, 38, 1565-1575. [CrossRef]

55. Rorig, M.L.; McKay, S.J.; Ferguson, S.A.; Werth, P. Model-Generated Predictions of Dry Thunderstorm Potential. J. Appl. Meteorol. Climatol. 2007, 46, 605-614. [CrossRef]

56. Wallmann, J.; Milne, R.; Smallcomb, C.; Mehle, M. Using the 21 June 2008 California Lightning Outbreak to Improve Dry Lightning Forecast Procedures. Weather Forecast. 2010, 25, 1447-1462. [CrossRef]

57. Rakov, V.A. A review of positive and bipolar lightning discharges. Bull. Am. Meteorol. Soc. 2003, 84, 767-776. [CrossRef]

58. Saba, M.M.F.; Pinto, O., Jr.; Ballarotti, M.G. Relation between lightning return stroke peak current and following continuing current. Geophys. Res. Lett. 2006, 33, L23807. [CrossRef]

59. Rosenfeld, D.; Fromm, M.; Trentmann, J.; Luderer, G.; Andreae, M.O.; Servranckx, R. The Chisholm firestorm: Observed microstructure, precipitation and lightning activity of a pyro-cumulonimbus. Atmos. Chem. Phys. 2007, 7, 645-659. [CrossRef]

60. Rudlosky, S.D.; Fuelberg, H.E. Seasonal, Regional, and Storm-Scale Variability of Cloud-to-Ground Lightning Characteristics in Florida. Mon. Weather Rev. 2011, 139, 1826-1843. [CrossRef]

61. Lang, T.J.; Rutledge, S.A.; Dolan, B.; Krehbiel, P.; Rison, W.; Lindsey, D.T. Lightning in Wildfire Smoke Plumes Observed in Colorado during Summer 2012. Mon. Weather Rev. 2014, 142, 489-507. [CrossRef]

62. McRae, R.H.D.; Sharples, J.J.; Fromm, M.D. Linking local wildfire dynamics to pyroCb development. Nat. Hazards Earth Syst. Sci. 2015, 15, 417-428. [CrossRef]

63. Dowdy, A.J.; Fromm, M.D.; McCarthy, N. Pyrocumulonimbus lightning and fire ignition on Black Saturday in southeast Australia. J. Geophys. Res. Atmos. 2017, 122, 7342-7354. [CrossRef]

64. Dowdy, A.J.; Ye, H.; Pepler, A.; Thatcher, M.; Osbrough, S.L.; Evans, J.P.; Di Virgilio, G.; McCarthy, N. Future changes in extreme weather and pyroconvection risk factors for Australian wildfires. Sci. Rep. 2019, 9, 10073. [CrossRef]

65. Mather, T.A.; Harrison, R.G. Electrification of volcanic plumes. Surv. Geophys. 2006, 27, 387-432. [CrossRef]

66. James, M.R.; Wilson, L.; Lane, S.J.; Gilbert, J.S.; Mather, T.A.; Harrison, R.G.; Martin, R.S. Electrical Charging of Volcanic Plumes. Space Sci. Rev. 2008, 137, 399-418. [CrossRef]

67. McNutt, S.R.; Williams, E.R. Volcanic lightning: Global observations and constraints on source mechanisms. Bull. Volcanol. 2010, 72, 1153-1167. [CrossRef]

68. Mendez Harper, J.; Dufek, J. The effects of dynamics on the triboelectrification of volcanic ash. J. Geophys. Res. Atmos. 2016, 121, 8209-8228. [CrossRef]

(C) 2020 by the author. Licensee MDPI, Basel, Switzerland. This article is an open access article distributed under the terms and conditions of the Creative Commons Attribution (CC BY) license (http://creativecommons.org/licenses/by/4.0/). 